\title{
Singapore: 2003 Article IV Consultation-Staff Report; Staff Supplement; and Public Information Notice on the Executive Board Discussion
}

Under Article IV of the IMF's Articles of Agreement, the IMF holds bilateral discussions with members, usually every year. In the context of the 2003 Article IV consultation with Singapore, the following documents have been released and are included in this package:

- the staff report for the 2003 Article IV consultation, prepared by a staff team of the IMF, following discussions that ended on December 15, 2003, with the officials of Singapore on economic developments and policies. Based on information available at the time of these discussions, the staff report was completed on February 23, 2004. The views expressed in the staff report are those of the staff team and do not necessarily reflect the views of the Executive Board of the IMF.

- $\quad$ a staff supplement of March 10, 2004 updating information on recent developments.

- $\quad$ a Public Information Notice (PIN) summarizing the views of the Executive Board as expressed during its March 15, 2004 discussion of the staff report that concluded the Article IV consultation.

The documents listed below have been or will be separately released.

Selected Issues Paper

Financial System Stability Assessment

The policy of publication of staff reports and other documents allows for the deletion of market-sensitive information.

To assist the IMF in evaluating the publication policy, reader comments are invited and may be sent by e-mail to publicationpolicy@imf.org.

Copies of this report are available to the public from

International Monetary Fund • Publication Services

$70019^{\text {th }}$ Street, N.W. • Washington, D.C. 20431

Telephone: (202) 623-7430 • Telefax: (202) 623-7201

E-mail: publications@imf.org・Internet: http://www.imf.org

Price: $\$ 15.00$ a copy

International Monetary Fund

Washington, D.C. 


\title{
INTERNATIONAL MONETARY FUND
}

\author{
SINGAPORE
}

\section{Staff Report for the 2003 Article IV Consultation}

Prepared by Staff Representatives for the 2003 Consultation with Singapore

Approved by Masahiko Takeda and Juha Kähkönen

February 23, 2004

- The 2003 Article IV consultation discussions were held in Singapore during December 3-15, 2003. The team comprised Messrs. Schwartz (head), Jang, and Eggertsson (all APD), Pedersen (ICM), and Brooks (RES). Ms. Tseng (APD) participated in discussions with senior officials during December 10-11, and Mr. Ishii (MFD) joined the mission to conclude the FSAP discussions during December 9-12.

- The mission met with Deputy Prime Minister Lee Hsien Loong (who also serves as the Minister of Finance and Chairman of the Monetary Authority of Singapore), MAS Managing Director Koh Yong Guan, other senior officials, and representatives of the private sector.

- In concluding the last Article IV consultation in December 2002, Directors commended the authorities for their skillful handling of the 2001 recession. They noted that the implementation of appropriate countercyclical policies had paved the way for a modest economic recovery. Directors also welcomed the authorities' timely new medium-term development strategy, with wide-ranging restructuring and liberalization measures to promote high-value-added activities, develop the services sector, and enhance labor market flexibility. They endorsed recent initiatives to increase the transparency of the monetary framework, and encouraged the authorities to enhance fiscal transparency. They welcomed Singapore's participation in the FSAP.

- The accompanying Financial Sector Stability Assessment (FSSA) concludes that Singapore's financial system remains robust, notwithstanding a number of severe economic shocks, and that regulatory and supervisory practices exhibit a high degree of observance of international standards and codes across all segments of the financial sector.

- Singapore has accepted the obligations of Article VIII, Sections 2, 3, and 4. It maintains an exchange system free of restrictions on payments and transfers for current international transactions. Singapore also provides data to the Fund on a generally timely basis, and is in observance of the SDDS. 


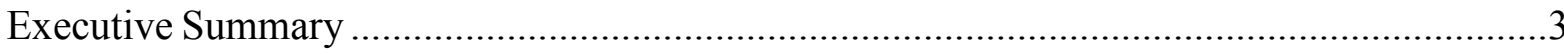

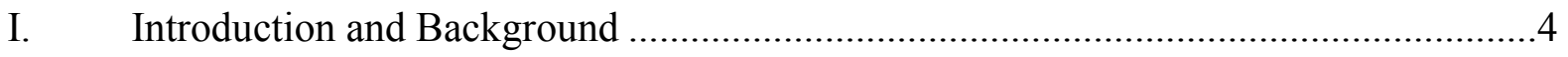

II. Recent Economic Developments .........................................................................

A. Macroeconomic and Market Developments ...................................................

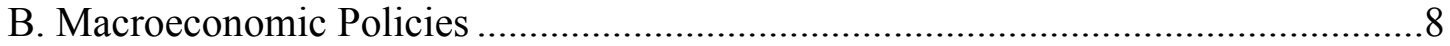

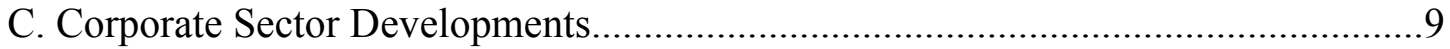

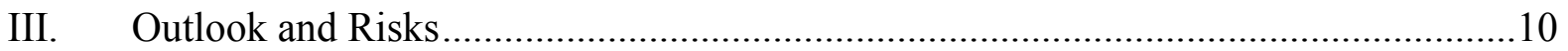

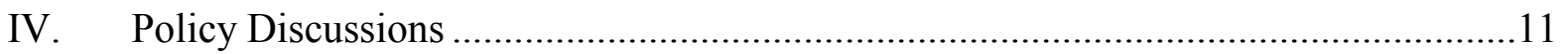

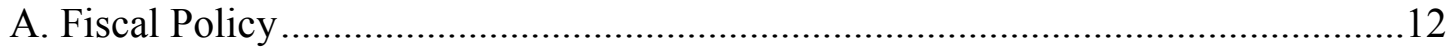

B. Exchange Rate and Monetary Policy ........................................................ 13

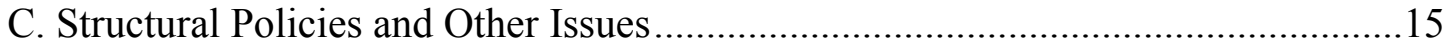

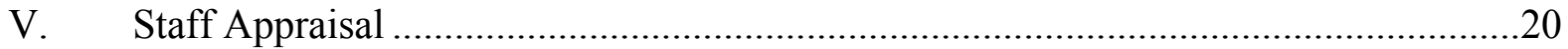

\section{Boxes}

1. Economic Impact of the SARS Outbreak and Policy Response.............................. 6

2. Changes in Monetary Policy Stance, 2001-03 .............................................. 9

3. Singapore's Free Trade Agreements.............................................................. 18

4. Findings of the Financial System Stability Assessment ...................................... 19

Figures

1. Regional Comparisons: Key Domestic Indicators ........................................... 22

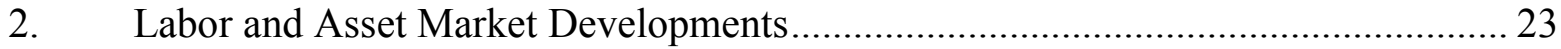

3. Regional Comparisons: Key External Indicators................................................ 24

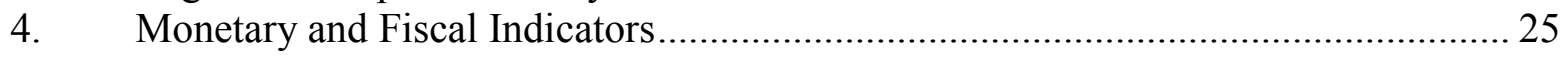

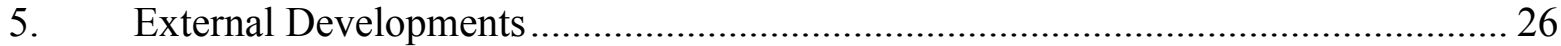

6. Current and Leading Indicators of Economic Activity ........................................ 27

Tables

1. Selected Economic and Financial Indicators, 1998-2004 _................................. 28

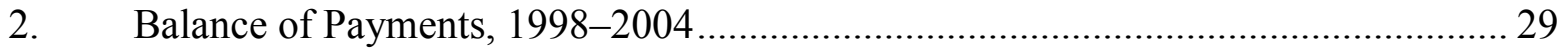

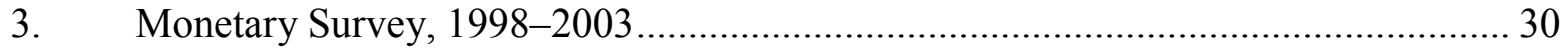

4. Summary of Government Operations, 1998/99-2003/04 ..................................... 31

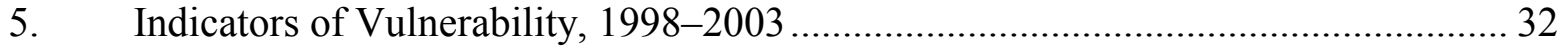

6. Illustrative Medium-Term Scenario, 2000-09 ................................................. 33

\section{Annexes}

I. Key Recommendations of the Economic Review Committee................................. 34

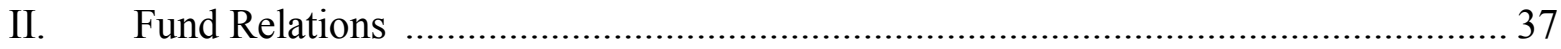

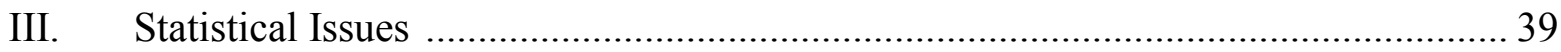




\section{EXECUTIVE SUMMARY}

\section{Background}

- The economy is recovering strongly in the aftermath of the SARS outbreak of early 2003. After contracting sharply in the second quarter of 2003, real GDP began to recover, with growth for the year registering almost 1 percent. Led by strong external demand, the outlook continues to improve, and GDP growth of around 5 percent is expected in 2004. Nevertheless, domestic demand has yet to revive, and unemployment remains high.

- The authorities responded to the SARS-induced economic downturn by adopting a supportive macroeconomic policy mix. Fiscal support was provided through a package of assistance to SARS-inflicted sectors of the economy. Monetary policy was eased midyear with the recentering of the exchange rate band around the prevailing lower level of the Singapore dollar. Supply-side measures were also adopted to reduce business costs.

- Concerns about Singapore's medium-term competitiveness and growth prospects have featured prominently in domestic policy discussions. The economy is facing competitive pressures from low-cost regional producers. The authorities have responded with reforms to make the economy more open and competitive, including most recently the endorsement of the recommendations of the Economic Review Committee (ERC). Key elements of the strategy include a reduction in tax rates, the divestment of government-linked companies (GLCs), and steps to foster labor market flexibility.

\section{Key Issues and Staff Recommendations}

- The mission welcomed the authorities' recent pragmatic use of macroeconomic policies to counter economic shocks. Given the sizeable output gap and still weak domestic demand, the staff encouraged the authorities to maintain a supportive macroeconomic policy stance until the recovery becomes more broad-based.

- To enhance Singapore's medium-term growth potential, the mission encouraged the authorities to accelerate and deepen structural reforms, including:

$>$ The divestment of GLCs, to foster the growth of the private sector and promote entrepreneurship.

$>$ Implementation of further reforms to the Central Provident Fund (CPF) to ensure adequate financial savings for retirees.

Adoption of further steps to enhance the transparency of economic information and policy making. Progress has been made in the area of monetary policy, but additional efforts would be desirable, especially with respect to fiscal policy.

- The FSAP exercise concluded that Singapore's financial sector remains robust, despite the economic downturn and declines in asset prices. The authorities agreed with the key FSAP findings and recommendations. 


\section{INTRODUCTION AND BACKGROUND}

1. After averaging over 9 percent in the decade prior to the Asian financial crisis, economic growth in Singapore has slowed markedly in recent years (Text Figure 1). This outcome is attributable to three major recent shocks: (i) the Asian crisis in 1997-98; (ii) the bursting of the tech bubble in 2000-01 (resulting in Singapore's worst recession since independence in 1965); and more recently, (iii) the outbreak of Severe Acute Respiratory Syndrome (SARS) in early 2003, exacerbated by uncertainties related to international terrorism and the war in Iraq.

2. The economic shocks have come as Singapore is also facing structural challenges owing to competition from low-cost regional

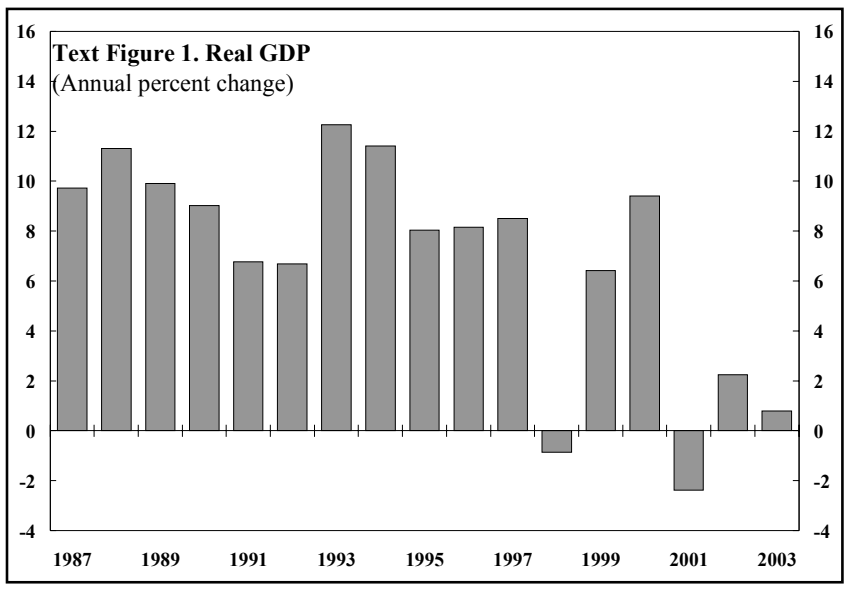
economies, including China and India. The economic downturns and an ongoing industrial restructuring toward capital-intensive sectors such as chemical and pharmaceuticals have contributed to rising unemployment. Concerns about Singapore's medium-term competitiveness and growth prospects, along with an increasing awareness of the economy's vulnerability to external shocks (especially in the electronics sector, which dominates the country's manufacturing exports), have featured prominently in domestic policy discussions. The economic slowdown has given rise to an internal re-examination of the appropriate role of the government in the economy, with concerns that Singapore's growth model based on extensive government involvement in the economy may be running out of steam.

3. In response to these challenges, over the past couple of years the authorities have undertaken a wide range of reforms to diversify and open the economy. Motivating the reforms has been a desire to maintain, if not enhance, Singapore's international competitiveness. Progress has been made in liberalizing the domestic banking, telecom, and utility sectors, enhancing the financial regulatory and supervisory framework, liberalizing the use of the Singapore dollar in international transactions, reaching free trade agreements with major trading partners, reforming the tax system, and increasing wage and labor market flexibility.

4. The reforms have been given further impetus with the authorities' official endorsement of the recommendations of the Economic Review Committee (ERC) (Annex I). The ERC was established in late 2001 to evaluate Singapore's long-term strategy and the need for structural change. Finalized in early 2003, the ERC recommendations seek to enhance competitiveness and entrepreneurship. Key elements of the strategy include a reduction in tax rates, the divestment of non-strategic government-linked companies (GLCs), and policies to foster greater labor market flexibility.

5. On the domestic political scene, the ruling People's Action Party (PAP), in power since independence, remains firmly in control (it retains an overwhelming majority in 
Parliament). In August 2003, Prime Minister Goh, who has been in office since 1990, announced that he would step down in the next one to two years. Deputy Prime Minister Lee Hsien Loong has been named as his successor. The next Parliamentary election is due by early 2007.

\section{RECENT ECONOMIC DEVELOPMENTS}

\section{A. Macroeconomic and Market Developments}

6. An economic recovery is underway in the aftermath of the SARS outbreak of March 2003 (Table 1):

- After a modest rebound from the recession of 2001, real GDP growth turned sharply negative in the second quarter of 2003, but has since recovered strongly. Output contracted by a near-record 10 percent (seasonally adjusted annualized $\mathrm{q} / \mathrm{q}$ basis) in the second quarter due to SARS (Text Figure 2 and Box 1). The services sector was hit particularly hard, especially tourism-related activities. Manufacturing output held up relatively well, with a rapidly expanding pharmaceuticals industry providing a counterbalance to weak electronics output. On the demand side, exports held up well, but

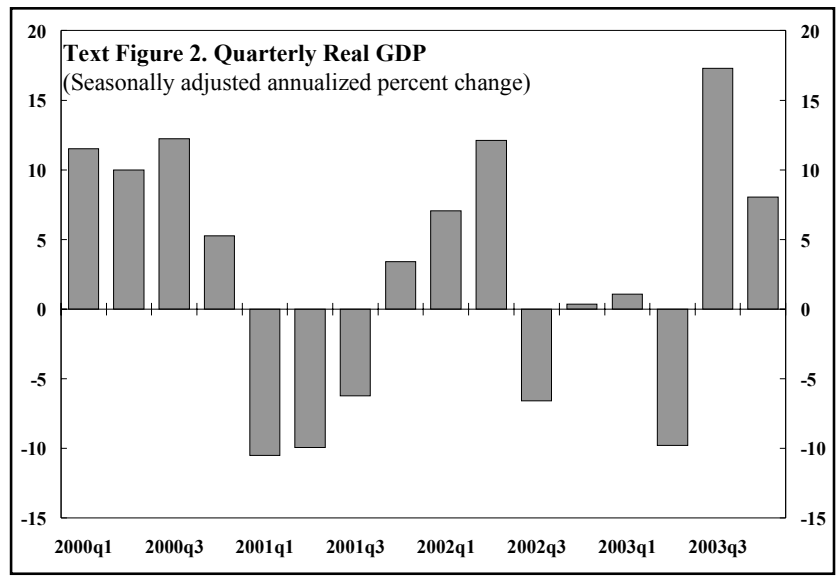
falling domestic demand (particularly investment) contributed to the sharp drop in activity. A recovery took hold in the second half of the year, led by strong external demand and a rebound in the services sector, although the construction sector continues to contract. For 2003 as a whole, real GDP is estimated to have increased by 0.8 percent.

\section{- Inflation has remained subdued} after a period of mild deflation in the year through October 2002 (Text Figure 3). CPI inflation has edged up in recent months, to 0.7 percent $(y / y)$ at end-2003. Despite some one-off cost-push factors, including an increase in the Goods and Services Tax (GST), weak domestic demand and soft labor market conditions continue to dampen any inflationary pressures. While

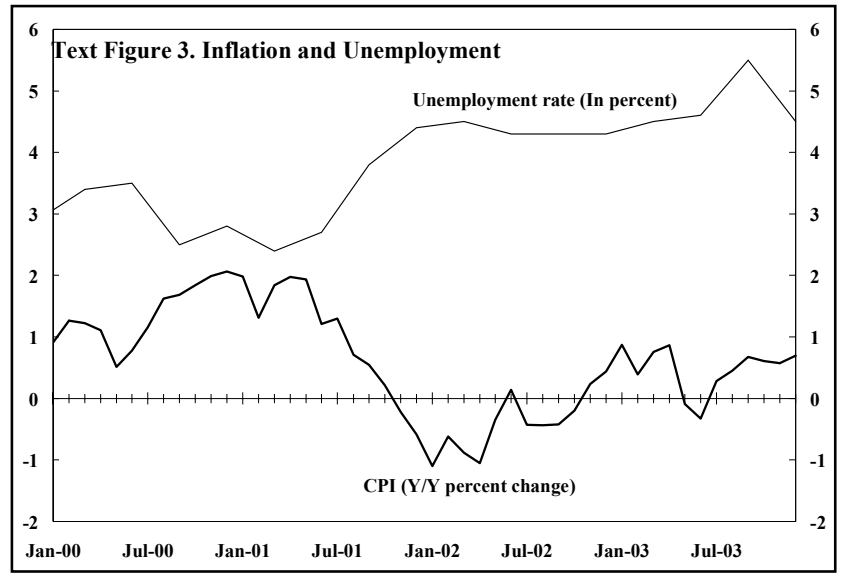




\section{Box 1. Economic Impact of the SARS Outbreak and Policy Response}

The Singapore economy was among the most severely affected by the outbreak of SARS. ${ }^{1}$ Together with the uncertainties in the external environment existing at the time, the SARS outbreak resulted in a near-record economic contraction in the second quarter of 2003 of 10 percent at a seasonally adjusted annualized rate. The staff's preliminary estimate indicates that the negative impact of SARS on annual growth amounts to about $1 \frac{1}{2}$ percentage points. The service sector (accounting for over 60 percent of GDP), including tourism and transport-related activities (such as hotels, restaurants, retail, airlines, and taxis), was most severely hit, as a result of the sharp decline in visitor arrivals, which declined by 71 percent (y/y) in May.

Business and consumer confidence were also adversely affected. The SARS outbreak did not, however, significantly affect the manufacturing sector nor external

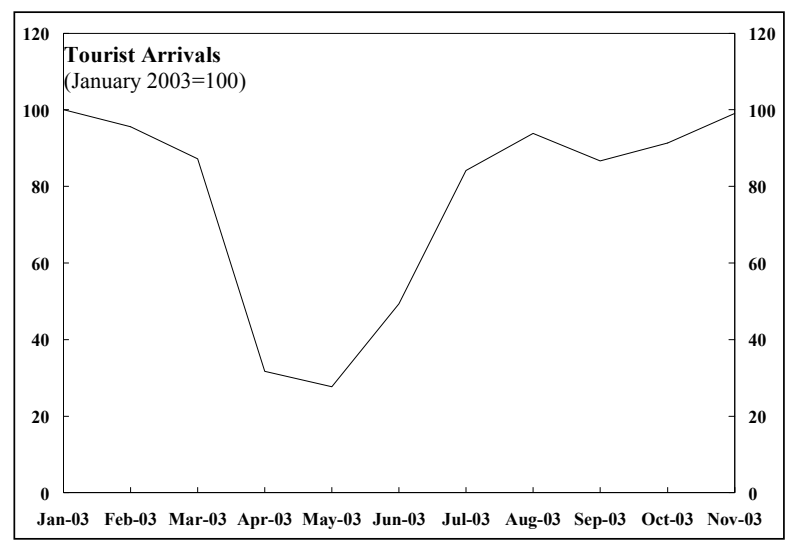
trade. A recovery has been under way in recent months; visitor arrivals and the hotel occupancy rate in December recovered to their pre-SARS levels.

In response to the economic downturn, the authorities have taken the following measures:

- The fiscal stance has become expansionary, with the revised budget for FY2003/04 targeting a surplus of 0.7 percent of GDP, down from 4.3 percent in the previous year. In particular, the government has implemented the following: (i) a S\$230 million aid package ( 0.2 percent of GDP) in April for the SARS-inflicted tourism and transport-related sectors; and (ii) a $\mathrm{S} \$ 1$ billion package of rebates, incentive schemes, and infrastructure projects $(0.6$ percent of GDP) in August to assist businesses, low-income earners, and the unemployed.

- On the supply side, steps have included: (i) several changes to the CPF (a fully funded mandatory pension scheme) to reduce business costs and save jobs, including a cut on October 1, 2003 in the employer contribution rate from 16 percent to 13 percent; and (ii) a reduction in civil service wages by 1-9 percent for the period July 2003-June 2004, in line with a recommendation in May by the tripartite National Wages Council.

- Monetary policy has also been eased to support the recovery. In July, the MAS eased policy by announcing that it would recenter its exchange rate policy band at the prevailing lower level of the nominal effective exchange rate, while maintaining a "zero percent appreciation" path and keeping the width of the band unchanged. The MAS estimated that the easier monetary policy stance taken since January 2002 would increase real GDP growth by $1 / 2$ percentage points in 2003.

${ }^{1}$ SARS first appeared in Singapore in mid-March, resulting in 32 deaths and 206 infections in the citystate. Singapore was officially removed from the list of SARS-affected areas on May 31 (an isolated case last September turned out not to result from local transmission). 
falling from a 17-year high of 5.5 percent in September 2003, unemployment remains high by historical standards. ${ }^{1}$

- A strong rebound in exports contributed to a sharp widening of the current account surplus, estimated at almost 30 percent of GDP in 2003 (Table 2). As elsewhere in Asia, a key driver of export growth has been demand from within the region, notably China. ${ }^{2}$ While electronics exports grew by 5 percent in 2003, reversing two consecutive years of contraction, gains were most apparent in non-electronics, particularly pharmaceuticals and chemicals (Text Figure 4). Import growth was sluggish through much of

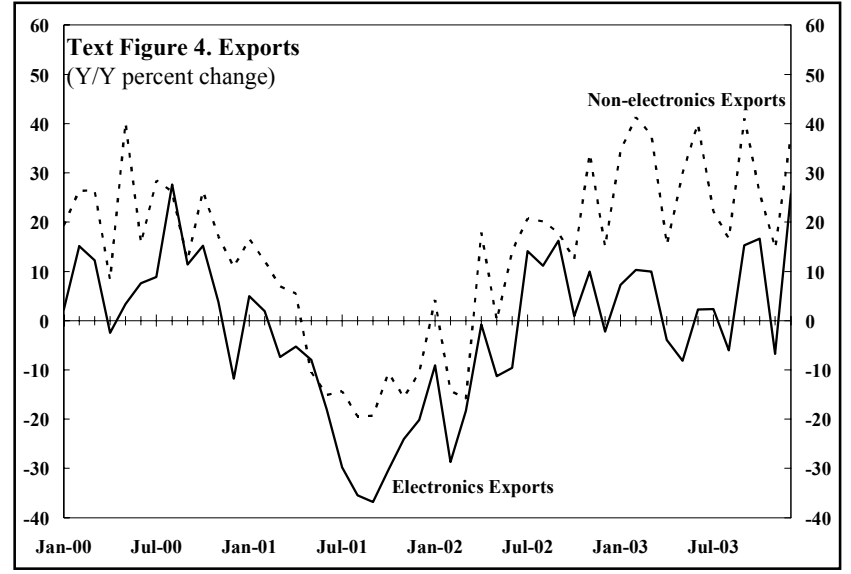
the year reflecting the weak domestic economic situation, although there was a sharp rise toward the end of the year. Official reserves increased by US\$14 billion during 2003, to stand at US\$96 billion (7 months of imports) at end-December.

- Bank lending has begun to rise since mid-2003, largely on robust gains in housing loans (Table 3 ). Loan growth to the corporate sector, which remained weak until early 2003, has also shown some tentative signs of strengthening. Domestic interest rates have remained low, consistent with

\begin{tabular}{|c|c|c|c|c|c|c|}
\hline \multicolumn{7}{|c|}{$\begin{array}{l}\text { Text Table 1. Key Financial Indicators for Local Banks } \\
\text { (In percent) }\end{array}$} \\
\hline & 1998 & 1999 & 2000 & 2001 & 2002 & Jan.-Sep. \\
\hline Capital adequacy & & & & & & \\
\hline Regulatory capital to risk-weighted assets & 18.1 & 20.6 & 19.6 & 18.1 & 16.9 & 17.8 \\
\hline \multicolumn{7}{|l|}{ Asset quality } \\
\hline Classified nonbank loans to total nonbank loans & 11.0 & 12.2 & 9.1 & 8.0 & 7.7 & 7.0 \\
\hline Classified loans to total loans & 7.8 & 8.5 & 5.5 & 5.7 & 5.5 & 5.3 \\
\hline \multicolumn{7}{|l|}{ Profitability } \\
\hline After-tax return on assets & 0.4 & 1.2 & 1.3 & 0.8 & 0.8 & 0.8 \\
\hline After-tax return on equity & 4.2 & 10.7 & 12.6 & 7.7 & 7.6 & 7.8 \\
\hline
\end{tabular}
trends in the global interest rate environment and ample liquidity in the domestic money market. Local bank balance sheets have remained healthy (Text Table 1).

${ }^{1}$ The spike in the September unemployment rate, to 5.5 percent in September from 4.6 percent in June, mainly reflected entrants into the labor force, which may have been attributable to the return of discouraged workers due to the improving economic outlook. Indeed, the decline in the unemployment rate in December reflected a stronger-than-expected pickup in the job market, led by services, but with manufacturing also registering employment growth, for the first time in three years.

${ }^{2}$ Non-oil exports to China grew by almost 35 percent in 2003, and have more than doubled since 2000. Taken together, exports to China and Hong Kong SAR have now overtaken the U.S. as Singapore's second largest export market. 
- Financial market sentiment has strengthened since mid-May 2003, in line with regional trends and the improving economic outlook (Text Figure 5). After declining modestly in 2002, equity prices rebounded by about 30 percent in 2003. Property prices have continued to decline, reflecting oversupply (particularly in the commercial market), but are showing signs of bottoming out.

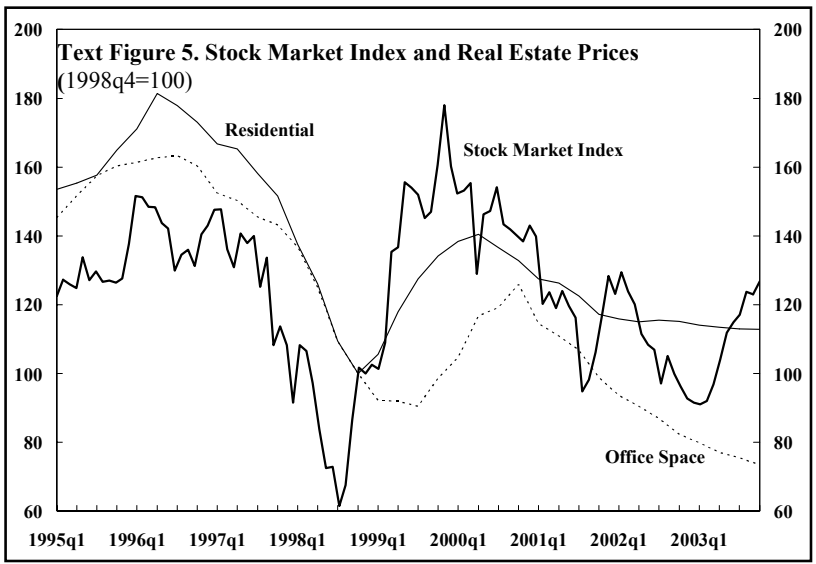

\section{B. Macroeconomic Policies}

7. The authorities implemented a number of fiscal measures in response to the SARS-induced economic downturn (Box 1). The FY2003/04 (April-March) fiscal stance has been expansionary, with the revised budget targeting a surplus of 0.7 percent of GDP (down from 4.3 percent in the previous year), amounting to a fiscal impulse of 1.8 percent of GDP according to staff estimates (Table 4). Building on structural measures contained in the original budget (including the implementation of various ERC recommendations), the revised budget provided additional stimulus, consisting largely of programs to assist low-income earners and the unemployed (including through utility rebates and training programs), and to accelerate infrastructure projects. Several supply-side measures to reduce business costs and support employment were also implemented, including a downward adjustment to the Central Provident Fund (CPF) employer contribution rate.

8. Monetary policy was also eased in July 2003 to support the recovery, with the exchange rate depreciating through much of the year (Text Figure 6 and Box 2). ${ }^{3}$ More recently, in October 2003, the MAS reaffirmed that it would maintain its current "neutral" policy stance to support the recovery. While the NEER depreciated by $3 \frac{1}{2}$ percent (period average) for the year, it has recently come under some appreciation pressure, as reflected in a sharp accumulation of international reserves (reserves rose by about US\$5 billion during the fourth quarter of 2003).

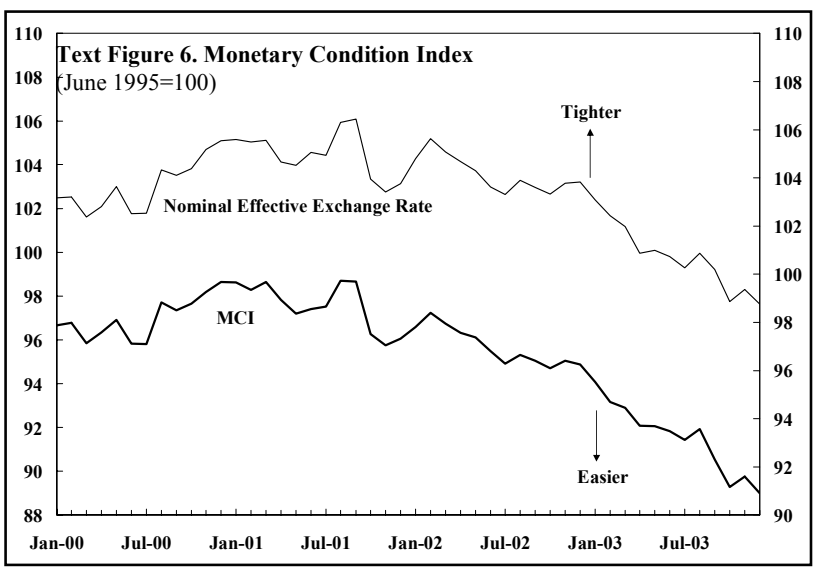

${ }^{3}$ Since 1981, monetary policy in Singapore has centered on the management of a tradeweighted exchange rate index within an undisclosed policy band, with the prime objective of promoting price stability. 


\begin{tabular}{|ll|}
\hline Buly 2001 & $\begin{array}{l}\text { Box 2. Changes in Monetary Policy Stance, 2001-03 } \\
\text { Shifted from a tightening to a neutral stance by centering the exchange rate policy band } \\
\text { on a "zero percent appreciation" path (i.e., a horizontal rather than upward sloping } \\
\text { band) of the trade-weighted exchange rate in response to a deterioration in the external } \\
\text { economic environment and a sharp downturn in the global demand for electronics. }\end{array}$ \\
October 2001 & $\begin{array}{l}\text { Widened the band (while maintaining a "zero percent appreciation" path) to } \\
\text { accommodate higher volatility in the aftermath of the September 11 events. }\end{array}$ \\
January 2002 & $\begin{array}{l}\text { Recentered and narrowed the band at the prevailing lower level of the trade-weighted } \\
\text { exchange rate to support economic recovery and as market volatility subsided. } \\
\text { Maintained a "zero percent appreciation" path. } \\
\text { Recentered the band at the prevailing lower level of the trade-weighted exchange rate to } \\
\text { support a recovery in the aftermath of the SARS outbreak, but maintained a "zero } \\
\text { percent appreciation" path and kept the width of the band unchanged. }\end{array}$
\end{tabular}

\section{Corporate Sector Developments}

9. The nonfinancial corporate sector has shown resilience to recent shocks, and has been consistently profitable (Text Table 2). The sector's resilience is due in part to relatively low debt-equity ratios, and high levels of liquidity. ${ }^{4}$ Despite these strengths, as noted above, the corporate sector is facing increasingly strong competitive pressures from low-cost regional producers and neighboring economies, and is undergoing structural changes to remain competitive, including the development of new industries and restructuring toward capital-intensive sectors.

\begin{tabular}{|c|c|c|c|c|c|c|}
\hline \multicolumn{7}{|c|}{ Text Table 2. Selected Indicators for the Nonfinancial Corporate Sector $1 /$} \\
\hline & 1996 & 1997 & 1998 & 1999 & 2000 & 2001 \\
\hline Debt-equity ratio & 0.8 & 0.9 & 1.0 & 0.8 & 0.8 & 0.8 \\
\hline Current ratio (current assets/current liabilities) & 1.0 & 1.0 & 1.0 & 1.0 & 1.1 & 1.1 \\
\hline \multicolumn{7}{|l|}{ Profitability } \\
\hline Return on asset (pre-tax) & 6.6 & 5.6 & 3.7 & 5.3 & 6.0 & 3.8 \\
\hline Return on equity (pre-tax) & 13.9 & 11.6 & 6.0 & 11.7 & 13.3 & 7.3 \\
\hline $\begin{array}{l}\text { Source: Singapore Department of Statistics. } \\
1 / \text { Data for } 2002 \text { and } 2003 \text { are not yet available. }\end{array}$ & & & & & & \\
\hline
\end{tabular}

\footnotetext{
${ }^{4}$ See the accompanying Selected Issues paper on Singapore's corporate sector and Box 3 of Financial System Stability Assessment (FSSA).
} 


\section{OUTLOOK AND RISKS}

10. With the economic recovery continuing to gain momentum, the near-term outlook has improved. Exports, manufacturing output, and tourism-related sectors are all now showing signs of strength. Moreover, with indications that the global IT sector is picking up, prospects for manufacturing and exports are relatively good. On the basis of continued strength in external demand and a continuation of the present policy stance, the staff projects real GDP growth to rebound by 5 percent in 2004 (toward the top of the authorities' official growth projection of 3-5 percent). While exports are expected to be the driver of the recovery, domestic demand should also begin to contribute, with a modest recovery in consumption as confidence improves and the unemployment rate declines, as well as a pickup in investment as the slack in the economy

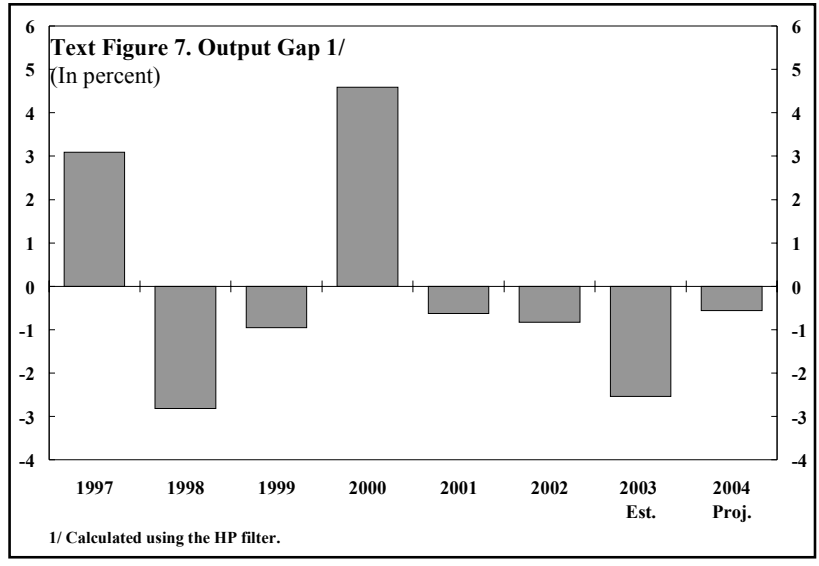
dissipates and inventories are rebuilt. Inflation is projected to remain modest at around 1 percent in 2004, due in part to the soft labor market conditions and persistent output gap (Text Figure 7).

11. The risks to the outlook are broadly balanced. The main downside risks relate to the strength of the global and regional recovery, and the possibility that unemployment and the still depressed property market could become drags on growth. Geo-political tensions, including the terrorism threat, and the possibility of a return of SARS, while diminishing, also pose risks. Nevertheless, as Singapore's external position and financial sector remain robust, the risk of an economic crisis is remote (Table 5). ${ }^{5}$ Moreover, there is upside potential to the 2004 projection, especially if the pickup of external demand gathers further momentum, and growth in the export sector spills over to domestic demand.

\footnotetext{
${ }^{5}$ The net international investment position was 52 percent of GDP at end-2002. Singapore does not have any external public debt, and consecutive years of fiscal surpluses have given rise to a substantial government net asset position estimated at over 50 percent of GDP. The stock of domestic public debt - amounting to about 100 percent of GDP at end-2003consists of CPF investments in nonmarketable government bonds, and government securities issued to stimulate development of the domestic capital market.
} 
12. The medium-term outlook depends on the success with which Singapore can restructure its economy to remain competitive with the region's low-cost producers. ${ }^{6}$ The emergence of China and other regional economies no doubt provides opportunities (Text Figure 8), but it also poses challenges. In addition to the loss of lower-end manufacturing, Singapore is competing for foreign direct investment flows. Competition from other regional financial centers and neighboring economies could also reduce the demand for Singaporebased financial intermediation, transportation, and shipping services over the medium term. Assuming that the loss of such industries can be minimized, and that the opportunities afforded by the region's expanded markets can be seized, the staff's estimates suggest that potential growth over the medium term is likely to be around 4-5 percent, in line with the authorities' estimates (Table 6$).^{7}$ The high level of the current account surplus is projected to narrow in the years ahead as the economy's high savings

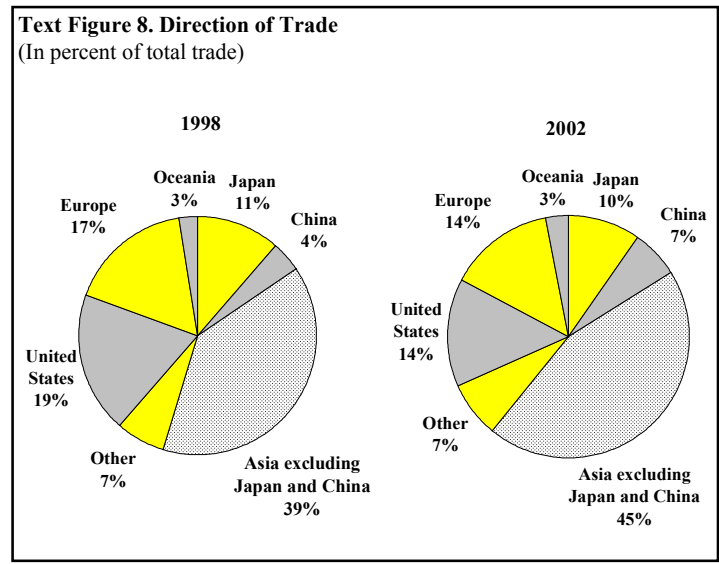
rate declines because of population ageing, and as investment recovers from its current low level.

\section{Policy Discussions}

13. With broad agreement on the assessment of the economic outlook, the discussions focused on the appropriate policy stance and on structural reforms needed to raise Singapore's medium-term growth potential. The thrust of the authorities' economic policies have been broadly in line with recent Fund recommendations (Text Table 3). Any differences have largely centered on the pace of reform rather than substance; on fiscal transparency, however, the authorities remain reluctant to proceed boldly due in part to concerns of a possible loss in policy flexibility, as well as credibility if targets are not met. The mission commended the authorities for their pragmatic use of countercyclical policies in

\footnotetext{
${ }^{6}$ While concerns at the sectoral level persist, standard indicators do not reveal an overall competitiveness problem at present (Figure 3). The real effective exchange rate remains competitive relative to regional economies, as do unit labor costs.

${ }^{7}$ Few observers expect growth to return to the high levels of the 1980s and 1990s, and the authorities consider the ERC's growth estimate of 3-5 percent in the medium term to be realistic. The drop in potential output growth relative to pre-crisis outturns might be explained by a number of factors, including Singapore's advanced stage of development, ongoing corporate restructuring in response to recent economic shocks and external competition, and a decline in investment rates over the last few years. See the accompanying Selected Issues paper for a more detailed assessment.
} 
response to adverse shocks over the past couple of yearsin contrast to earlier periods when policies were focused almost exclusively on medium-term objectives - and, with domestic demand still weak, encouraged them to maintain a supportive policy stance until the recovery becomes more broad-based. With respect to structural reforms, the staff welcomed the government's endorsement of the ERC recommendations, but noted that they were somewhat incremental and had fallen short of market expectations. The mission encouraged the authorities to consider deepening and accelerating reforms in key areas to foster private sector growth and enhance the economy's flexibility. The authorities agreed that further reforms would be desirable over time, but preferred to proceed cautiously.

\section{A. Fiscal Policy}

14. The mission commended the authorities on their move to an expansionary fiscal policy in 2003/04, and urged that a supportive stance be maintained in the coming year. In the staff's view, there was still ample room for fiscal support given the government's strong net asset position, resulting from several consecutive years of accumulated budget surpluses. The authorities explained that they could have provided even more stimulus in 2003/04, but had exercised restraint, as in their view further stimulus would have been ineffective given the sizeable leakages due to Singapore's high degree of external openness. ${ }^{8}$

\section{The authorities were still in the very early stages of preparing the 2004/05}

budget (for submission to Parliament in late February). ${ }^{9}$ They agreed with the staff on the merits of maintaining a supportive stance in the coming year-by aiming for an unchanged fiscal stance (i.e., unchanged structural surplus) - in light of the still weak domestic demand

${ }^{8}$ Calls by retailers to defer the scheduled GST increase on January 1, 2004 (from 4 percent to 5 percent) were rejected as (i) the size of the increase was modest; (ii) the contractionary impact would be offset by the distribution of "Economic Restructuring Shares" (a form of financial transfer designed to compensate consumers for increase in the GST); and (iii) the increase had already been partially postponed - a 2 percentage point increase, from 3 percent to 5 percent had originally been planned for January 1, 2003.

${ }^{9}$ An update on the policies and key parameters underlying the 2004/05 budget will be provided for the forthcoming Board discussion. 
conditions. To achieve this, they envisaged further initiatives on the tax side through additional income tax cuts and rebates (a reduction in the top personal and corporate income tax rate from 22 to 20 percent is envisaged by 2005, in line with the ERC recommendations) rather than spending initiatives, whose effectiveness they believe is limited. The mission largely agreed with this strategy, but saw scope for additional spending in the form of targeted assistance to unemployed workers. In addition to cushioning the impact on displaced workers, the staff emphasized that, as Singapore currently has only a very limited program in place to provide financial assistance to unemployed workers, introduction of a well-designed and targeted scheme could enhance labor market flexibility by removing obstacles to labor retrenchment and job search. While agreeing that additional labor market flexibility would be desirable, the authorities noted that wage flexibility was already increasing, and emphasized that they had put into place a number of job training and search facilitation programs.

\section{Over the medium term the authorities explained that they plan to gear fiscal} policy toward achieving broad balance. The staff asked whether such an approach was excessively cautious given the authorities' substantial net asset position. The authorities responded that they see scope to respond flexibly to short-term economic shocks, but prefer to be guided by the overall objective of protecting the budget in anticipation of rising health care and social services costs associated with an ageing population. They emphasized that, as Singapore lacks natural resources to fall back on during hard times, one of their key mediumterm policy objectives is to save accumulated surpluses as a cushion against unforeseen shocks.

17. The mission emphasized that there is scope to enhance the transparency of fiscal information and policy making. It noted that the limited availability of information continues to hamper fiscal policy analysis. In particular, information on consolidated government accounts remains unavailable, notably with respect to the operation of statutory boards and the government's investment income. The mission also noted that it would be helpful to publish a medium-term budget framework, and to provide information on the financial operations of the Government Investment Corporation (GIC). The authorities agreed with the merits of publishing consolidated fiscal accounts, but explained that various technical issues involving reconciliations of cash versus accrual accounting still needed to be addressed. They remained reluctant, however, to publish a medium-term budget framework, given their desire to retain policy flexibility by not committing to any specific fiscal path, and also concern about a potential loss of credibility if the targets were not achieved. The mission encouraged the authorities to undertake a fiscal ROSC, as they had previously indicated would be considered upon completion of the FSAP. They authorities said that a ROSC was still under consideration, but that no decision had yet been reached.

\section{B. Exchange Rate and Monetary Policy}

18. In view of the low inflation rate and widened output gap, the mission expressed support for maintaining an easy monetary policy stance. The authorities explained that they intended to maintain a supportive stance until evidence of inflationary pressures begins to emerge, which they did not anticipate in the near term. The staff agreed that the level of the trade-weighted exchange rate appeared broadly appropriate, especially in light of cyclical 
conditions; once the recovery took hold, there would be scope for some tightening of the current easy monetary policy stance, consistent with the price stability objective which, together with the economic recovery, would enable Singapore to contribute to the adjustment of global current account imbalances. In the authorities' view, the substantial widening of the current account surplus largely reflected weaknesses in domestic demand and structural factors. ${ }^{10}$ They expected the surplus to narrow as domestic demand picks up with the economic recovery.

\section{The authorities considered that their exchange rate based monetary policy} framework continues to perform well, and do not envisage significant changes. While agreeing that the framework is functioning smoothly, the staff noted that it appeared to loosely resemble an inflation targeting approach, consistent with the MAS' objective of price stability. ${ }^{11}$ If so, the staff inquired whether there might be gains to adopting such a framework explicitly. The authorities explained that they prefer not to adopt rigid rules in their approach to monetary policy making, but to maintain flexibility in response to shocks. They indicated that they are continuing to evaluate the operation of the monetary regime on an ongoing basis, and would be prepared to make changes in the future if warranted by economic circumstances. For the time being, they envisaged that any changes going forward would be in the direction of strengthening the efficiency of the framework through measures to enhance transparency (below) and improve understanding of the transmission mechanism through which the exchange rate affects the real economy.

\section{The mission welcomed recent initiatives by the MAS to enhance the} transparency of its monetary policy framework and policy setting process. Steps over the past couple of years include publication of the twice-yearly Macroeconomic Review and Monetary Policy Statement (which, among other things, discloses the broad parameters of the policy band), dissemination of a series of monographs and guides on monetary policy operations, and provision of information to market participants on money market transactions. Such steps have enhanced the market's understanding of monetary operations and, in the view of the authorities, have improved the effectiveness of the MAS' policy instruments. Nevertheless, the mission noted that there was still scope to clarify monetary policy implementation, and encouraged the authorities to continue to make further efforts to enhance the transparency and market's understanding of the framework. The authorities explained that they continue to prefer not to disclose the weights used in the trade-weighted exchange rate index or precise limits of the band. They emphasized, moreover, that they had already provided sufficient information to the markets to enable analysts to make wellinformed estimates of these parameters. The authorities indicated that they will nevertheless continue to assess the benefits of releasing additional information against the possible impact

\footnotetext{
${ }^{10}$ As described in the accompanying Selected Issues paper, demographics (i.e., ageing population) may be a key structural factor underlying the current account surplus.

${ }^{11}$ Previous staff research has revealed that the authorities place a high weight on controlling inflation (see "Singapore's Unique Monetary Policy: How Does It Work?” WP/04/10).
} 
on policy effectiveness, and will proceed with efforts to enhance transparency, such as through the annual publication of a review of MAS' monetary operations.

21. In line with the recommendations of the FSAP team, the mission also encouraged the authorities to address the potential for conflicts of interest from the multiple functions of the MAS Chairman (who currently also serves as Minister of Finance). While conflicts of interest have so far not arisen, due in part to the government's historically strong fiscal position, the authorities were receptive to this recommendation, and were planning to address it through a review of the MAS Act. They argued, however, that a limited pool of qualified public servants to fill such positions meant that officials had to serve occasionally in dual functions.

22. The mission inquired about the authorities' plans with respect to removing the remaining restrictions on the use of the Singapore dollar in international transactions. ${ }^{12}$ The authorities considered the remaining restrictions to be effective in deterring currency speculation. They did not believe that the restrictions were inhibiting economic transactions, a view confirmed by the mission's and FSAP team's discussions with market participants. Nevertheless, they continue to evaluate the pros and cons of retaining the restrictions, and may consider their elimination in the future.

\section{Structural Policies and Other Issues}

23. While the shocks of the past several years have posed challenges for short-term economic management, the most significant policy issues are structural. Increasing competition from low-cost regional economies - both in the service and manufacturing sectors - has raised concerns within Singapore about the economy's medium-term competitiveness and growth prospects. The government's endorsement of the ERC recommendations is a response to these challenges, and builds on efforts of recent years to liberalize and diversify the economy and promote flexibility. Of particular importance are measures to enhance competitiveness and entrepreneurship through, among other things, divestment of non-strategic GLCs, a shift from direct to indirect taxation, an increase in the variable component of wages, reforms to the CPF scheme aimed at enhancing its core retirement savings objective, and a strengthening of job training programs.

24. The mission encouraged the authorities to accelerate their planned divestment of GLCs. The authorities maintained that the GLCs are run on commercially sound principles and do not act as a drain on the public finances. Nevertheless, the mission emphasized that the public sector retains ownership in GLCs across a broad range of economic activities, and that anecdotal evidence suggests that GLCs may be stifling competition and

12 In 2002, all but two restrictions on the use of the Singapore dollar in international transactions were removed. The remaining restrictions pertain to: (i) the requirement that nonresident financial entities swap Singapore dollar proceeds into foreign currency to finance activities abroad; and (ii) a prohibition on the extension of credit facilities (in excess of S\$5 million) by domestic financial institutions to nonresidents for speculative purposes. 
entrepreneurship. To foster private sector initiative and enhance the economy's ability to respond to external competition, therefore, the mission emphasized that it would be desirable to step up the GLC divestment process, particularly with respect to small- and medium-sized GLCs, in which there was not an obvious role for the government. The authorities noted that their objective was to privatize GLCs, except in cases where national strategic and security interests are at stake (i.e., key utilities, transportation networks, and social services), or where a given corporation has the potential to grow beyond the domestic market (consistent with the ERC recommendations and Temasek Charter, which call for GLCs to maintain an outward orientation). They noted that a number of firms had been wholly or partially divested in recent years, and that they planned to continue this process as market conditions permit. To clarify the government's role in GLCs, they also planned to publish a list of all GLCs during the course of 2004. The mission noted that it would also be desirable to develop and publish a broad timeframe for planned divestments. The authorities, however, preferred to approach divestments on a case-by-case basis, and argued that the divestment schedule was constrained in part by the limited pool of domestic entrepreneurial talent available to purchase and run GLCs effectively.

25. The mission discussed other ways to enhance the economy's competitiveness. The authorities noted that they have taken a number of steps, with recent measures including cuts in corporate and personal income tax rates, a reduction in the employer contribution rate to the CPF (below), reductions in user fees and charges, and the implementation of programs to facilitate job search and training. The mission suggested that an acceleration of planned tax cuts could be considered; while Singapore's income tax rates are low by international standards, its corporate tax rate is still some $4 \frac{1}{2}$ percentage points above that in Hong Kong SAR. The mission also suggested that ongoing reviews of government fees and charges, including with respect to rents on industrial land owned by the government, could be helpful in determining the scope for further lowering business costs. The authorities broadly agreed with these suggestions, but did not see scope to accelerate tax cuts, given their objective of ensuring adequate revenues in advance of the fiscal demands associated with an ageing population.

26. While recent reforms to the CPF seek to ensure adequate savings for retirement, the mission noted that achieving this goal would require further efforts over time. The authorities' reform initiatives have been designed to address shortcomings in the CPF savings scheme; despite a relatively high contribution rate (currently set at 33 percent of wages, subject to a salary ceiling), retirees often find themselves short of sufficient liquid financial savings. ${ }^{13}$ To enhance the return to savings portfolios, CPF contributors have been permitted

${ }^{13}$ These shortcomings were documented in a recent Selected Issues paper (IMF Country Report No. 00/83). The CPF was established in 1955 as a core retirement scheme, but over time has been amended by permitting withdrawals from retirement accounts for specified purposes in order to advance various national objectives, including universal home ownership. Given the large share of wealth held in the form of home ownership, retirees in Singapore often face the dilemma of being "asset rich, but cash poor." 
to invest a portion of their savings in privately managed investment funds. Rules for withdrawing contributions for purposes other than saving for retirement have also been tightened, with a notable reduction in the amounts available for housing financing. Even after these initiatives, however, the projected income replacement ratio (defined as the amount of cash available at retirement as a share of recent wage earnings) remains low, at about 20-40 percent, according to the government's estimates. The authorities accepted the need for further reforms, which will become more pressing after the year 2010, when the number of retirees is projected to accelerate (Text Figure 9). The mission therefore encouraged them to consider a more fundamental reform of the CPF system, which would, among other things, further reduce withdrawals from retirement accounts for home financing. Moreover, with wage flexibility on the rise, the mission encouraged the authorities to refrain from adjusting the employer contribution rate as a counter-

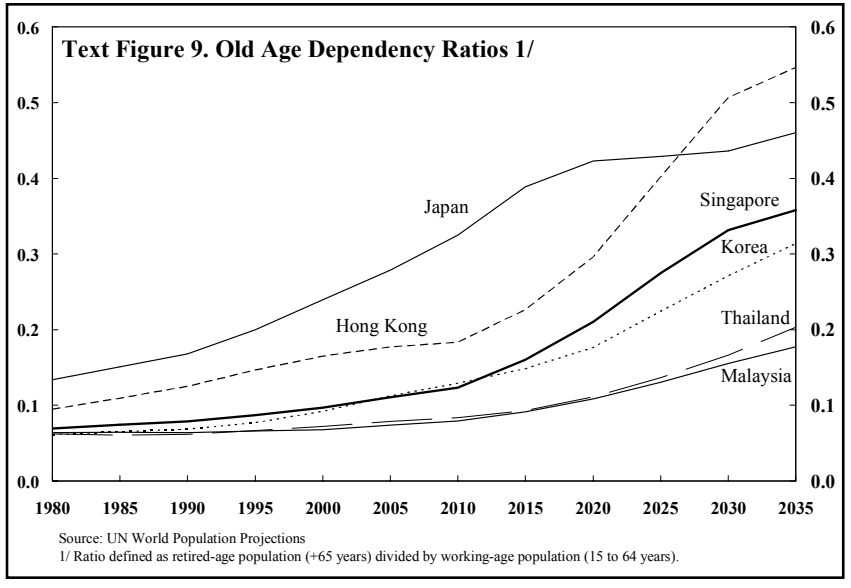
cyclical instrument (the authorities currently envisage a variable rate of 10-16 percent, or an overall contribution rate of 30-36 percent, which would fluctuate depending on economic conditions). The mission argued that an early return to a stable contribution rate would assist in refocusing the CPF toward its core savings objective.

27. The mission commended the authorities on their continued support of free trade. The authorities explained that they remained fully committed to the multilateral approach to trade liberalization, including in the context of the Doha Round. They have also aggressively pursued free trade agreements, having concluded a pact over the last year with the United States (Box 3). The authorities view their free trade agreements as useful catalysts for regional and broader multilateral initiatives.

\section{The FSAP team concluded that Singapore's financial sector remains robust,} despite the series of economic shocks and asset price declines of the past few years (Box 4 and attached Financial System Stability Assessment). Both local and major foreign bank branches remained profitable, and their balance sheets healthy. The authorities agreed with the FSAP findings, and noted that they were already taking steps to address the key recommendations, including a review of the MAS Act with a view to strengthening the MAS' accountability and independence. The authorities are also reviewing the relatively high capital adequacy requirements for local banks (12 percent of total risk-weighted assets), which have put pressure on local banks' returns on equity. The authorities were relatively optimistic about Singapore's ability to retain its status as a major financial center over the medium term. They noted in particular Singapore's reputation for good governance, strong macroeconomic fundamentals, well-developed infrastructure, and sound legal and regulatory framework. While pressures were increasing from lower-cost regional competitors, the authorities believed that Singapore was likely to retain higher-value added activities. The main constraint, in their view, was related to the small size of the domestic market and the 


\section{Box 3. Singapore's Free Trade Agreements}

Singapore is highly trade-dependent, with one of the highest trade-to-GDP ratios in the world (at over 270 percent of GDP). The country is a member of various multilateral and regional trade organizations, including the WTO and ASEAN. In addition to participating in multilateral initiatives, the authorities have also sought bilateral free trade agreements (FTAs), which they believe serve as a catalyst to broader trade liberalization initiatives, and have concluded discussions with a number of strategic trading partners. Singapore's bilateral FTAs are WTO-compliant and are viewed by the authorities as complements to other multilateral initiatives. FTAs have been concluded with New Zealand, Japan, European Free Trade Association (EFTA), Australia and the U.S. (below), and negotiations are ongoing with ASEAN, Canada, China, Korea, India, Jordan, Mexico, "Pacific-3," Panama, and Sri Lanka. As Singapore has almost no import tariffs (apart from tariffs on six categories of alcoholic beverages), the concessions it has offered to negotiating partners have mainly involved foreign access to service industries in Singapore (such as banking), stronger protection of intellectual property rights, and introduction of a new competition law to level the playing field for companies competing against Singaporean firms. ${ }^{1}$

An important agreement was reached last August, when Singapore and the U.S. concluded an FTA (the U.S. is Singapore's largest source of foreign investment and its second largest trading partner, constituting 14 percent of its total trade). The agreement came into force on January 1, 2004, and marks the first bilateral FTA signed by the U.S. with an Asian state. Its primary goal is to open up the U.S. market further to Singapore's merchandise exports, in return for access by U.S. firms to Singapore's service sector, particularly the financial sector. The agreement also encompasses intellectual property rights and electronic commerce. Under the terms of the treaty the U.S. is to eliminate tariffs on all products originating from Singapore (92 percent of such tariffs will be eliminated within the first four years of the FTA). This would result in an estimated $\$ \$ 200-300$ million worth of tariff savings per year for Singapore companies. In return, Singapore is to remove its existing tariffs on goods (alcoholic beverages) from the U.S.

Another significant FTA was implemented with Japan in 2002. The Japan-Singapore FTA is similar in scope to the U.S. treaty, with about 94 percent of Singapore's exports to Japan being made duty-free. In return, Singapore has removed its tariffs on imports from Japan and provided access to its service sector. The treaties with Australia, New

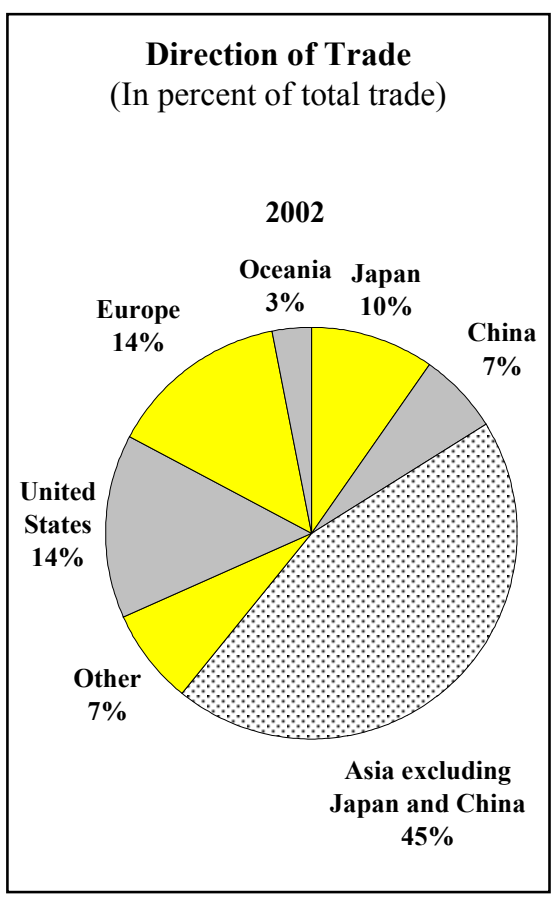
Zealand and the European Free Trade Area (EFTA) are likely to have a relatively smaller economic impact, since these economies account for a fairly small share of Singapore's total trade (see figure).

\footnotetext{
${ }^{1}$ Any negative welfare effects of trade diversion on Singapore would be minimal given the absence
} of tariffs. 


\section{Box 4. Findings of the Financial System Stability Assessment}

The recent FSAP exercise determined that Singapore's financial system remains robust, even after the recent economic downturns and substantial asset price declines. Singapore's local banks, which dominate the domestic retail banking sector, are profitable and well capitalized. They are also liquid, adequately provisioned for nonperforming asset exposures, and conservative in their management practices. The insurance sector is also well capitalized and profitable overall. Its links to the banking sector are not systemically important despite some cross-ownership. Stress test results indicate that Singapore's systemically important banks (including major foreign bank branches) and insurance companies could still withstand significant shocks.

The FSAP team found that regulatory and supervisory practices exhibit a high degree of observance of international standards and codes across all segments of the financial sector. Singapore's financial sector also benefits from an efficient legal system, accounting standards that closely follow international best practices, and ongoing initiatives to promote good corporate governance and strengthen the framework of disclosure practices.

Nevertheless, there is scope for MAS to further enhance regulatory and supervisory practices. The FSAP team's recommendations include: (i) further enhancing the legal and regulatory frameworks for risk-based capital requirements; (ii) reducing the potential for conflicts of interest arising from the multiple responsibilities of the Chairman of the MAS; (iii) disclosing more information on recent developments in the financial sector and supervisory actions to enable the public to better assess the supervisory performance of MAS under the risk-based regulatory framework; and (iv) strengthening macro prudential monitoring in the areas of cross-border flows, derivative activities, and the balance sheets of the household and corporate sectors.

While the MAS' conservative regulatory and supervisory framework has helped local banks weather a series of adverse shocks, it may also serve to constrain local banks' future growth. Local banks have consistently reported strong returns on assets, but their relatively high capitalization rates have limited their equity returns compared with many internationally active banks. The MAS is reviewing the regulatory minimum requirements for capital.

A further deepening of the corporate bond market would help to diversify funding sources for the corporate sector. Notwithstanding a number of recent initiatives to facilitate market development, the corporate bond market in Singapore is not yet at an advanced stage of development. Market growth has been constrained by the size and structure of the domestic economy and ample liquidity in the banking system. To further boost bond market activity, the FSAP team has encouraged the authorities to review and address factors that may constrain the corporate bond market, including the limited use of credit ratings, the guaranteed interest rates of the CPF, and the CPF investment policy which segments large long-term funds from local capital markets.

Singapore has in place a sound and comprehensive legal, institutional, policy and supervisory framework for AML/CFT. The legal system is well regarded, with a low crime rate, an intolerance for corruption, and an efficient judiciary. Nevertheless, there is scope for improving the effectiveness of cross border mutual legal assistance. 
lack of a natural "hinterland" (such as the role that China plays for Hong Kong SAR). They plan to address these shortcomings through policies to further develop the domestic capital market and wealth management industry. ${ }^{14}$

\section{Staff Appraisal}

29. The Singapore economy is recovering from another turbulent year. Following the shocks associated with the Asian financial crisis and bursting of the tech bubble over the last several years, the economy was buffeted in 2003 by the fallout from the SARS epidemic, resulting in a sharp economic contraction during the second quarter. Nevertheless, output growth for the year remained positive, at close to 1 percent, and a strong economic recovery has taken hold, led by external demand. GDP growth for 2004 appears likely to reach around 5 percent, and could well be even higher. While the outlook has brightened, the unemployment rate remains high by historical standards, and the authorities recognize the importance of addressing structural reforms if the economy is to meet the challenges of rising competitive pressures from low cost regional producers over the medium term.

30. The authorities are to be commended for their pragmatic macroeconomic policy response to the economic downturn in 2003. Supportive fiscal and monetary policies helped to cushion the impact of the SARS-induced economic shock. While it is appropriate for the authorities to retain a medium-term focus for economic policies, they should be prepared to continue to use macroeconomic policy instruments to counter economic shocks, given Singapore's high degree of exposure to the volatile external environment.

31. Fiscal policy in FY2003/04 became appropriately expansionary, with the revised budget providing welcome stimulus in response to the economic downturn. The initiatives to provide targeted support to SARS-inflicted sectors of the economy were particularly welcome, as were measures to support wage flexibility to maintain competitiveness and ease the impact on employment. With domestic demand still recovering, the authorities are encouraged to maintain a supportive fiscal policy stance in period ahead.

\section{The easing of monetary policy in July 2003 through the announced recentering} of the MAS' exchange rate policy band was also welcome. In the absence of inflationary pressures, and with domestic demand still weak, it remains appropriate to maintain a supportive monetary policy stance. Once the recovery takes hold, there should be scope for some tightening of the current easy monetary policy stance, consistent with the price stability objective which, together with the economic recovery, would enable Singapore to contribute to the adjustment of global current account imbalances. While the MAS' monetary policy framework centered on the management of the trade-weighted exchange rate has continued to serve the economy well, the authorities have made welcome strides to improve the effectiveness of the framework by enhancing the transparency of the policy setting process and disseminating operational background materials to the market. The staff encourages that such efforts be continued.

\footnotetext{
${ }^{14}$ See the accompanying Selected Issues paper on bond market development.
} 
33. The authorities appropriately recognize that the most significant policy challenges they face over the medium term are on the structural reform front. Rising competition from the region's low costs producers is fostering structural changes in the economy, shifting from lower end manufacturing and services to higher value added activities. The government's endorsement of the ERC recommendations is helpful, as their implementation over time will help foster entrepreneurship and improve the economy's overall competitiveness. Of special importance are initiatives to lower income tax rates, enhance labor market flexibility, and reduce the government's role in the economy through the divestment of GLCs. Nevertheless, further efforts will be needed to meet the competitive challenges that lie ahead. The staff encourages the authorities to consider accelerating the divestment of GLCs where possible, in order to promote entrepreneurship and increase the role of the private sector. The staff commends recent initiatives to ensure adequate savings for retirees under the CPF scheme. Steps taken in recent years to increase the returns to assets by permitting savers to invest in privately managed investment funds are welcome, as are efforts to shift the scheme away from promotion of housing financing back toward the CPF's core function as a retirement scheme. In this regard, the staff also encourages the authorities to consider an early return to a stable contribution rate.

\section{The FSAP has concluded that Singapore's financial system is resilient to} economic shocks, and remains healthy after the economic downturns of recent years. Good progress has been made to strengthen the legal and regulatory framework for riskbased supervision. The staff also welcomes the ongoing review of the MAS Act, which seeks to address the potential for conflict arising from the multiple official responsibilities of the Chairman of the MAS, and to improve the institutional decision-making process and disclosure policy. This initiative should help to safeguard Singapore's track record of good performance and the future integrity of the monetary and financial policy framework. The authorities are also encouraged to implement the remaining recommendations of the FSAP team, including to enhance the transparency of how supervisory decisions are taken, disclose more information to assess supervisory performance, and strengthen the MAS' macroprudential monitoring.

35. There is scope to enhance the transparency of fiscal policy information. The authorities are encouraged to develop and publish consolidated sets of fiscal accounts, and to provide more information on the government's investment income, including with respect to the financial operations of the GIC. Such efforts would facilitate fiscal policy analysis.

36. It is recommended that the next Article IV consultation with Singapore be held on the standard 12-month cycle. 
Figure 1. Singapore: Regional Comparisons: Key Domestic Indicators
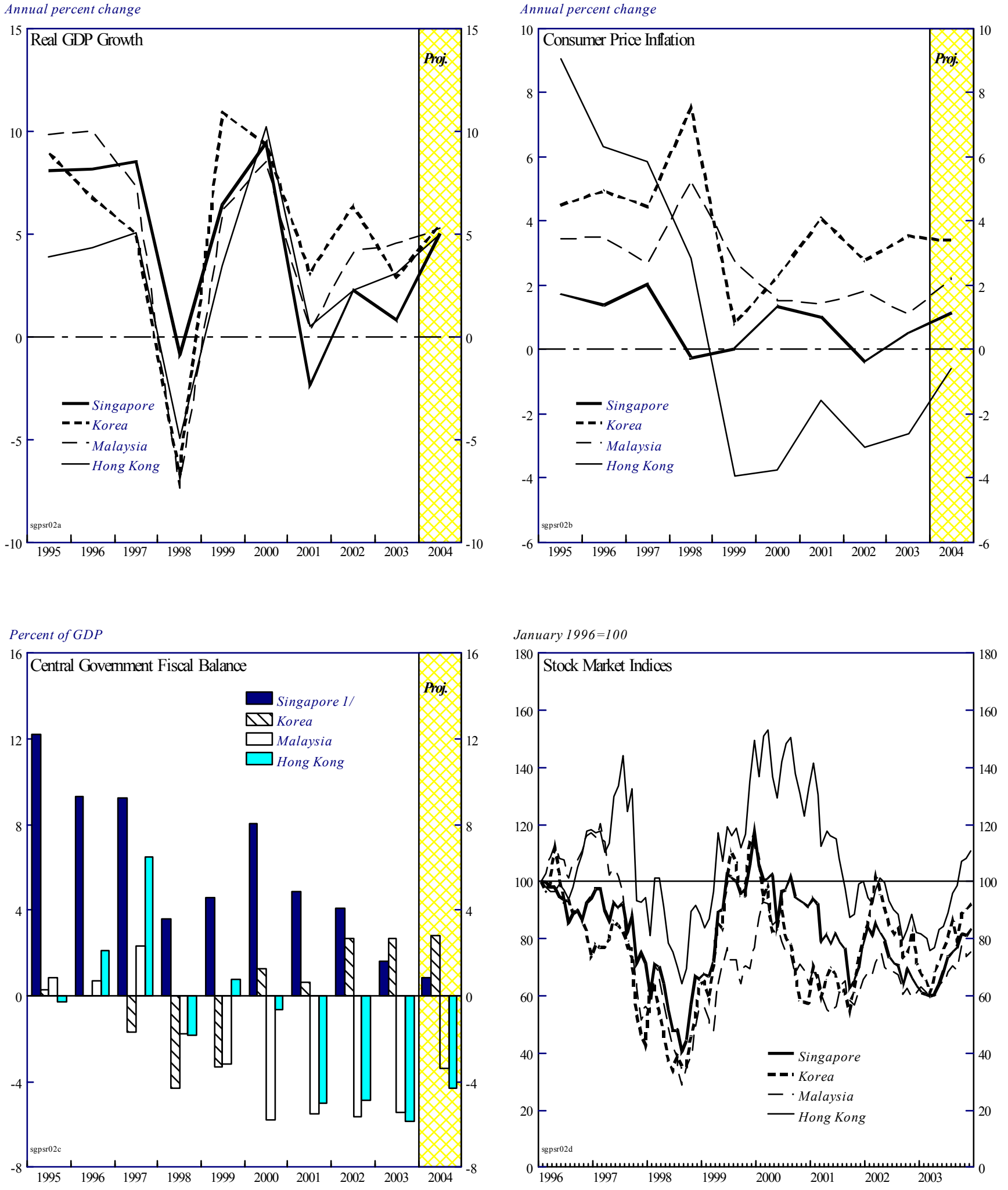

Sources: IMF, World Economic Outlook, Information Notice System, and data provided by the Singapore authorities. 
Figure 2. Singapore: Labor and Asset Market Developments
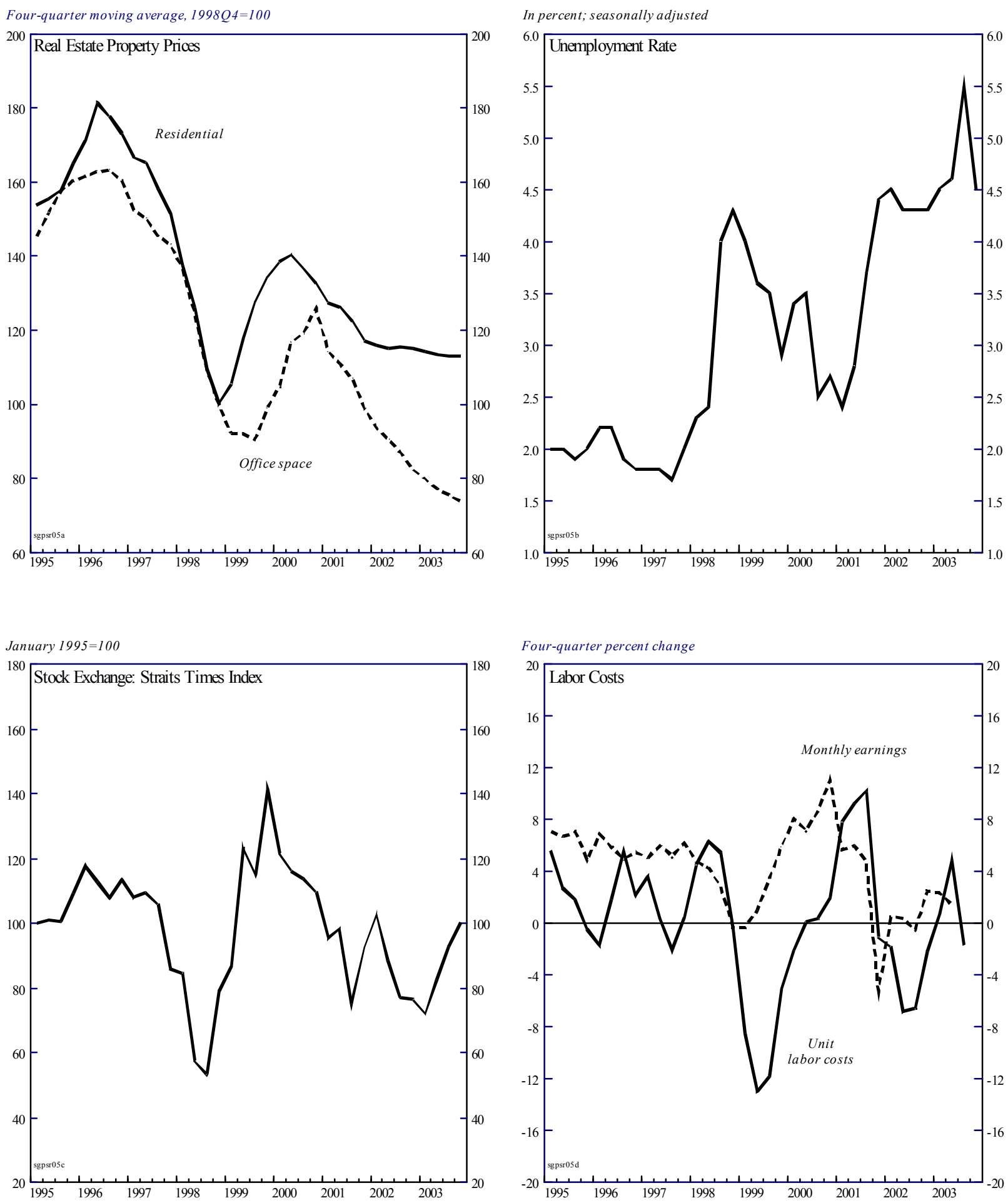
Figure 3. Singapore: Regional Comparisons: Key External Indicators
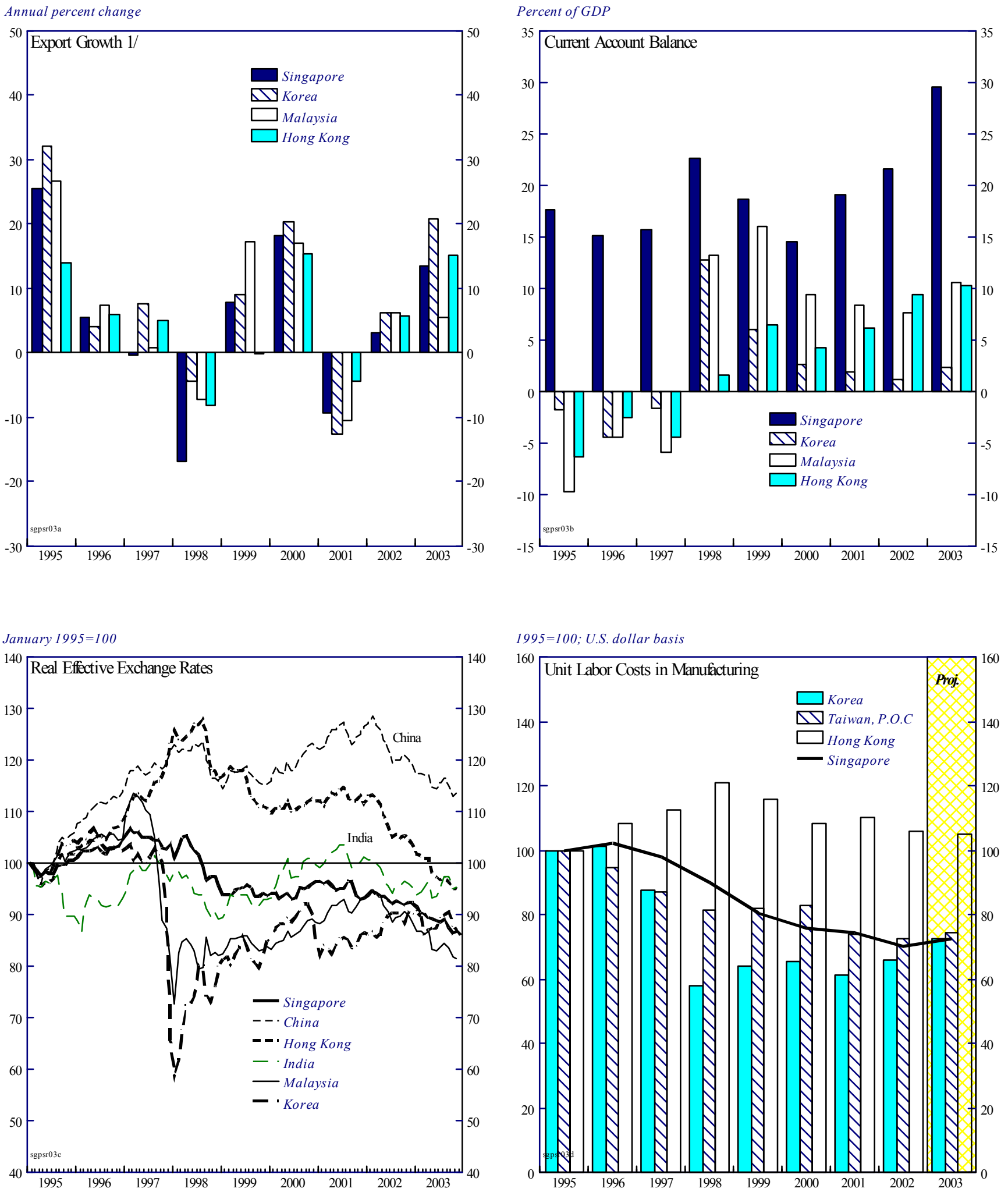

Sources: IMF, World Economic Outlook, Information Notice System, and data provided by the Singapore authorities. 
Figure 4. Singapore: Monetary and Fiscal Indicators
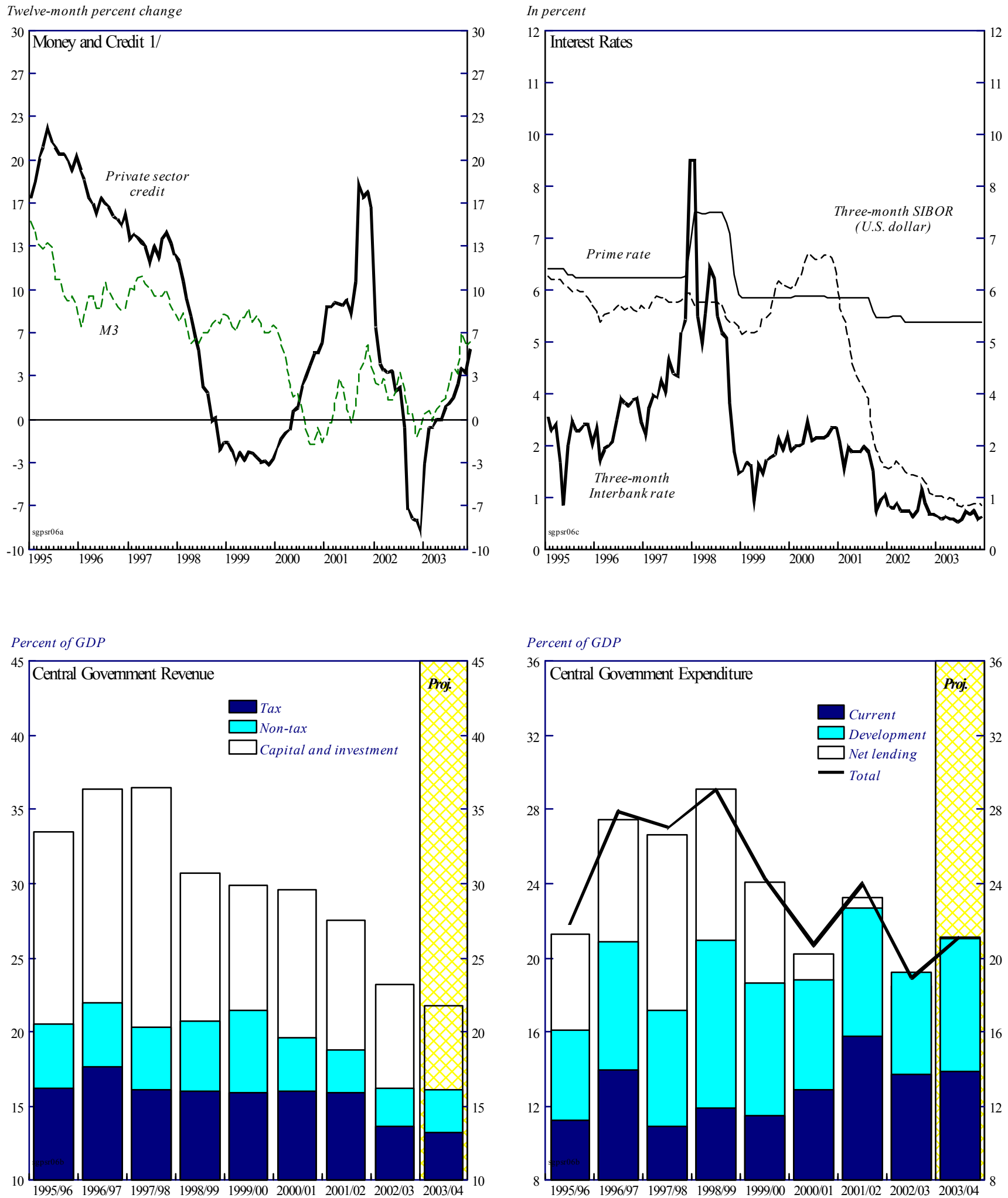

Sources: CEIC Database; and data provided by the Singapore authorities.

1/ Adjusted for the purchase of POSBank by DBS Bankin November 1998. 
Figure 5. Singapore: External Developments
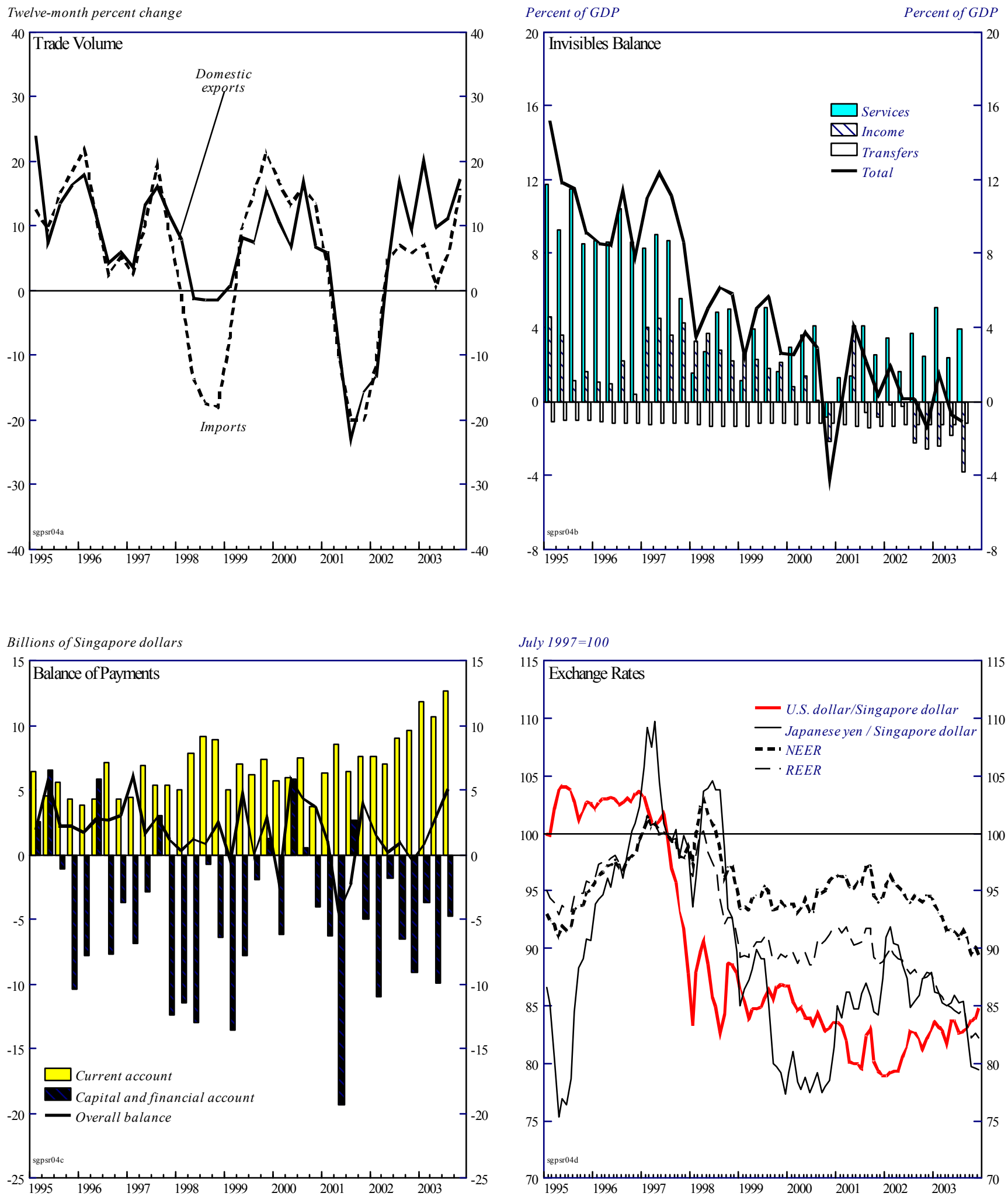
Figure 6. Singapore: Current and Leading Indicators of Economic Activity
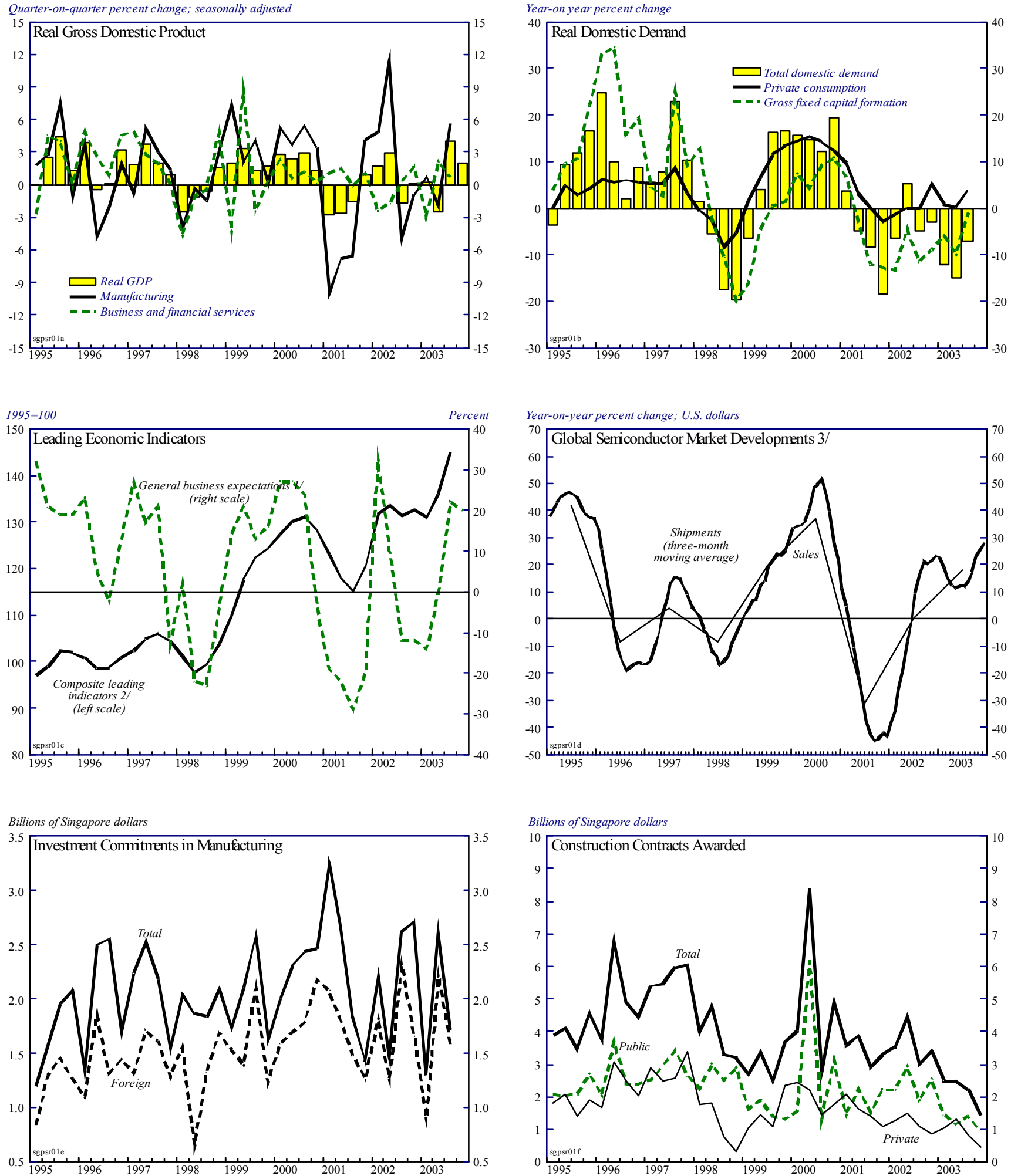

Sources: Data provided by the Singapore authorities.

1/ Percentage change of firms expecting an improvement in business conditions in the manufacturing sector.

$2 /$ The composite leading index has nine components which include money stock, stock of finished goods, company formation, wholesale

price changes in manufactured goods, inverted real unit labor costs for manufacturing, inverted default rates for manufacturing,

the business forecast for wholesale trade, new orders, and the stock price index

3/ Based on data by the Semiconductor Industry Association. Reflects value of shipments in a single month. Sales data are on an annual basis. 
Table 1. Singapore: Selected Economic and Financial Indicators, 1998-2004

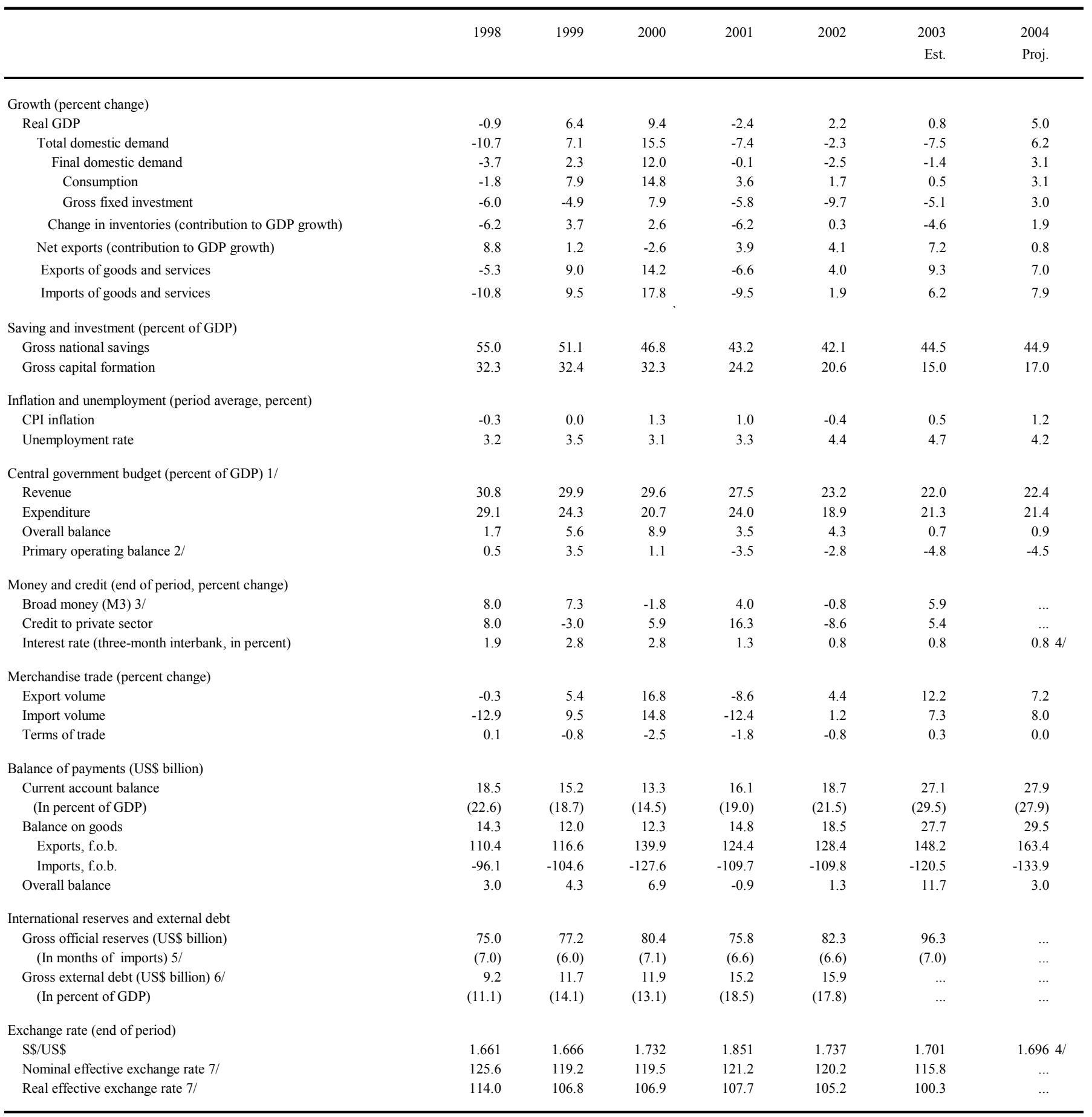

Sources: Data provided by the Singapore authorities; and Fund staff estimates and projections.

1/ Fiscal year beginning on April 1.

2/ Overall balance excluding capital revenue, investment income, net lending, debt service, and fund transfers.

3/ Adjusted for the acquisition of POSBank by the Development Bank of Singapore in November 1998.

4/ As of February 6, 2004.

$5 /$ In months of next year's imports of goods and services.

6/ Based on BIS data; corporate bonds outstanding and the external bank claims by the BIS reporting countries.

7/ IMF Information Notice System monthly index $(1990=100)$; period average. 
Table 2. Singapore: Balance of Payments, 1998-2004 1/

(In billions of U.S. dollars)

\begin{tabular}{|c|c|c|c|c|c|c|c|}
\hline & 1998 & 1999 & 2000 & 2001 & 2002 & $\frac{2003}{\text { Est. }}$ & $\frac{2004}{\text { Proj. }}$ \\
\hline Current account balance & 18.5 & 15.2 & 13.3 & 16.1 & 18.7 & 27.1 & 27.9 \\
\hline Trade balance & 14.3 & 12.0 & 12.3 & 14.8 & 18.5 & 27.7 & 29.5 \\
\hline Exports, f.o.b. & 110.4 & 116.6 & 139.9 & 124.4 & 128.4 & 148.2 & 163.4 \\
\hline Of which: electronics exports & 59.7 & 63.0 & 77.0 & 64.1 & 65.1 & $\ldots$ & $\ldots$ \\
\hline Imports, f.o.b. & -96.1 & -104.6 & -127.6 & -109.7 & -109.8 & -120.5 & -133.9 \\
\hline Services balance & 2.9 & 2.4 & 2.2 & 2.0 & 2.4 & 3.0 & 2.8 \\
\hline Income balance & 2.4 & 1.8 & -0.1 & 0.5 & -1.1 & -2.5 & -3.1 \\
\hline Transfer payments (net) & -1.1 & -1.0 & -1.1 & -1.1 & -1.1 & -1.1 & -1.2 \\
\hline Net capital flows 2/ & -15.6 & -10.9 & -6.4 & -17.0 & -17.4 & -15.4 & -24.9 \\
\hline Capital and financial account balance & -18.9 & -12.9 & -2.1 & -15.5 & -15.8 & -13.0 & -24.9 \\
\hline Capital account (net) & -0.2 & -0.2 & -0.2 & -0.2 & -0.2 & -0.2 & -0.2 \\
\hline Financial account (net) & -18.7 & -12.8 & -1.9 & -15.4 & -15.7 & -12.8 & -24.7 \\
\hline Direct investment (net) & 7.2 & 7.9 & 6.4 & 1.4 & 2.0 & 3.5 & 3.5 \\
\hline Portfolio investment (net) & -9.5 & -8.9 & -13.5 & -11.1 & -12.6 & -10.4 & -13.8 \\
\hline Other investment (net) & -16.5 & -11.7 & 5.2 & -5.7 & -5.0 & -5.9 & -14.4 \\
\hline Net errors and omissions & 3.3 & 2.1 & -4.3 & -1.5 & -1.6 & -2.4 & 0.0 \\
\hline Overall balance & 3.0 & 4.3 & 6.9 & -0.9 & 1.3 & 11.7 & 3.0 \\
\hline \multicolumn{8}{|l|}{ Memorandum item: } \\
\hline Current account as percent of GDP & 22.6 & 18.7 & 14.5 & 19.0 & 21.5 & 29.5 & 27.9 \\
\hline \multicolumn{8}{|l|}{ Net international investment postion } \\
\hline (In billions of U.S. dollars) & $\ldots$ & $\ldots$ & $\ldots$ & 40.4 & 45.1 & $\ldots$ & $\ldots$ \\
\hline (In percent of GDP) & $\ldots$ & $\ldots$ & $\ldots$ & 47.6 & 51.8 & $\ldots$ & $\ldots$ \\
\hline
\end{tabular}

Sources: Monetary Authority of Singapore, Economic Survey of Singapore; and Fund staff estimates and projections.

1/ Data for the current account balance, the capital and financial account balance, and net errors and ommissions are converted to U.S. dollars from the official presentation in Singapore dollars using period-average exchange rate.

2/ Including net errors and omissions. 
Table 3. Singapore: Monetary Survey, 1998-2003

\begin{tabular}{|c|c|c|c|c|c|c|c|c|c|}
\hline Net foreign assets & 115.5 & 131.0 & 126.3 & 132.9 & 133.2 & 140.1 & 144.1 & 141.9 & 149.0 \\
\hline Monetary authorities & 124.3 & 127.1 & 137.8 & 138.6 & 141.5 & 146.3 & 151.4 & 156.1 & 160.7 \\
\hline Domestic credit (net) & 122.1 & 121.8 & 126.6 & 144.6 & 121.3 & 125.1 & 127.2 & 128.7 & 133.2 \\
\hline Claims on private sector & 154.9 & 150.2 & 159.1 & 185.1 & 169.1 & 168.0 & 172.7 & 174.6 & 177.0 \\
\hline Claims on government (net) & -32.8 & -28.4 & -32.5 & -40.4 & -47.7 & -42.9 & -45.5 & -45.8 & -43.8 \\
\hline Other items (net) & -76.9 & -78.3 & -82.1 & -96.6 & -74.2 & -81.7 & -86.7 & -85.5 & -88.7 \\
\hline Quasi-money & \multicolumn{9}{|c|}{ (Annual percentage change) } \\
\hline Domestic credit & 18.2 & -0.3 & 4.0 & 14.2 & -16.1 & -4.7 & -2.4 & 6.3 & 8.8 \\
\hline Claims on private sector & 8.0 & -3.0 & 5.9 & 16.3 & -8.6 & -0.6 & 1.0 & 2.8 & 3.6 \\
\hline M2 & 30.2 & 8.5 & -2.0 & 5.9 & -0.3 & 0.5 & 2.9 & 4.8 & 7.7 \\
\hline M3 & 8.0 & 7.3 & -1.8 & 4.0 & -0.8 & -0.1 & 1.7 & 3.6 & 5.6 \\
\hline
\end{tabular}

Source: International Financial Statistics, IMF.

1/ Commercial banks. 
$-31-$

Table 4. Singapore: Summary of Government Operations, 1998/99-2003/04

(In percent of GDP)

\begin{tabular}{|c|c|c|c|c|c|c|c|c|}
\hline & \multirow[t]{2}{*}{ 1998/99 } & \multirow[t]{2}{*}{$1999 / 00$} & \multirow[t]{2}{*}{$2000 / 01$} & \multirow[t]{2}{*}{$2001 / 02$} & \multicolumn{2}{|c|}{$2002 / 03$} & \multicolumn{2}{|c|}{$2003 / 04$} \\
\hline & & & & & Budget & Act. & Budget 1/ & Proj. 2/ \\
\hline Total revenue & 30.8 & 29.9 & 29.6 & 27.5 & 23.4 & 23.2 & 22.2 & 22.0 \\
\hline Current revenue & 24.3 & 26.1 & 25.4 & 24.4 & 21.7 & 21.5 & 20.9 & 20.8 \\
\hline Tax revenue & 16.0 & 15.9 & 16.0 & 16.0 & 14.4 & 13.7 & 13.6 & 13.4 \\
\hline Investment income 3/ & 3.6 & 4.6 & 5.8 & 5.5 & 4.8 & 5.2 & 4.6 & 4.6 \\
\hline Other nontax revenue & 4.7 & 5.6 & 3.6 & 2.9 & 2.5 & 2.5 & 2.8 & 2.8 \\
\hline Capital revenue 4/ & 6.4 & 3.8 & 4.2 & 3.2 & 1.7 & 1.7 & 1.2 & 1.2 \\
\hline Total expenditure & 29.1 & 24.3 & 20.7 & 24.0 & 21.2 & 18.9 & 20.6 & 21.3 \\
\hline Current expenditure & 11.9 & 11.5 & 12.9 & 15.7 & 13.2 & 13.7 & 13.7 & 14.0 \\
\hline Operating expenditure & 10.9 & 10.4 & 11.5 & 12.2 & 12.3 & 12.3 & 12.5 & 12.9 \\
\hline Debt servicing & 0.7 & 0.6 & 0.3 & 0.3 & 0.3 & 0.3 & 0.2 & 0.2 \\
\hline Agency fees on land sales & 0.0 & 0.0 & 0.0 & 0.0 & 0.0 & 0.0 & 0.0 & 0.0 \\
\hline Investment expenses & 0.2 & 0.2 & 0.4 & 0.4 & 0.7 & 0.3 & 0.6 & 0.6 \\
\hline Transfer payments & 0.0 & 0.3 & 0.6 & 2.7 & 0.0 & 0.8 & 0.4 & 0.4 \\
\hline Development expenditure and net lending & 17.2 & 12.6 & 7.3 & 7.5 & 8.0 & 4.8 & 6.9 & 7.3 \\
\hline Development expenditure 5/ & 9.1 & 7.2 & 5.9 & 6.9 & 6.6 & 5.5 & 6.9 & 7.2 \\
\hline Net lending & 8.1 & 5.4 & 1.4 & 0.6 & 1.4 & -0.7 & 0.1 & 0.1 \\
\hline Fund transfers $6 /$ & 0.0 & 0.2 & 0.5 & 0.7 & 0.0 & 0.4 & 0.0 & 0.0 \\
\hline Overall balance & 1.7 & 5.6 & 8.9 & 3.5 & 2.2 & 4.3 & 1.5 & 0.7 \\
\hline Primary operating balance $7 /$ & 0.5 & 3.5 & 1.1 & -3.5 & -2.7 & -2.8 & -4.0 & -4.8 \\
\hline \multicolumn{9}{|l|}{ Memorandum items: } \\
\hline Government saving & 12.5 & 14.4 & 12.0 & 7.9 & 8.4 & 7.3 & 7.2 & 6.8 \\
\hline Structural primary operating balance 8 / & 1.3 & 3.4 & 0.1 & -3.2 & -2.5 & -2.6 & -3.6 & -4.4 \\
\hline Fiscal impulse based on operating balance 9/ & 2.2 & -2.1 & 3.3 & 3.3 & -0.6 & -0.5 & 0.9 & 1.8 \\
\hline Government domestic debt $10 /$ & 84.0 & 91.2 & 85.2 & 98.0 & $\ldots$ & 100.7 & $\ldots$ & 103.6 \\
\hline Of which: Central Provident Fund & 43.5 & 45.4 & 38.4 & 58.8 & $\ldots$ & 60.6 & $\ldots$ & 62.3 \\
\hline
\end{tabular}

Sources: Data provided by the Singapore authorities; and Fund staff estimates and projections.

1/ Original budget, excluding supplementary budgets. Fiscal year runs from April 1 through March 31.

2/ Includes supplementary budget measures announced in mid-April and in late August.

3/ Includes all investment income from government assets and interest earnings on development loans from 2000/01.

4/ Sale of government property.

5/ Includes the land reclamation expenditure.

6/ Includes transfers to the Edusave Endowment Fund, the Medical Endowment Fund, the Lifelong Learning Endowment Fund and the ElderCare Fund.

7/ Overall balance excluding investment income, capital revenue, debt service, net lending, and fund transfers.

8 / Calculated with the elasticity of revenue with respect to output equal to 1.1 , and a zero elasticity of expenditure with respect to output.

9/ Calculated as an increase in the structural primary operating deficit.

10/ Data for end of calendar year.

11/ As of end-September. 
Table 5. Singapore: Indicators of Vulnerability, 1998-2003

\begin{tabular}{|c|c|c|c|c|c|c|c|}
\hline \multicolumn{8}{|l|}{ Financial sector indicators } \\
\hline Private sector credit (percent change, $y / y$ ) & 8.0 & -3.0 & 5.9 & 16.3 & -8.6 & 5.4 & Dec-03 \\
\hline Credit to the property sector (percent change, $y / y$ ) & 16.7 & 2.1 & 9.6 & 6.4 & 2.4 & 12.2 & Dec-03 \\
\hline Share of property-sector credit in total non-bank credit (percent) & 37.8 & 39.8 & 41.7 & 41.9 & 43.4 & 45.8 & Dec-03 \\
\hline NPL ratio (Singapore-incorporate banks, percent) & 11.0 & 12.2 & 9.1 & 8.0 & 7.7 & 7.0 & Sep-03 \\
\hline Capital adequacy ratio of local banks (percent) & 18.1 & 20.6 & 19.6 & 18.1 & 16.9 & 17.8 & Sep-03 \\
\hline \multicolumn{8}{|l|}{ Asset market indicators } \\
\hline Stock prices (percent change, $\mathrm{y} / \mathrm{y}$ ) & -7.6 & 78.0 & -22.3 & -15.7 & -17.4 & 31.6 & Dec-03 \\
\hline $\mathrm{P} / \mathrm{E}$ ratio & 19.0 & 99.2 & 20.9 & 16.8 & 21.2 & 24.5 & Nov-03 \\
\hline \multicolumn{8}{|l|}{ External Indicators } \\
\hline Current account balance (US\$ billion) & 18.5 & 15.2 & 13.3 & 16.1 & 18.7 & 7.2 & 2003Q3 \\
\hline (In percent of GDP) & 22.6 & 18.7 & 14.5 & 19.0 & 21.5 & 30.6 & 2003Q3 \\
\hline Gross official reserves (US\$ billion) & 75.0 & 77.2 & 80.4 & 75.8 & 82.3 & 96.3 & Dec-03 \\
\hline (In month of next year's imports of goods and services) & 7.0 & 6.0 & 7.1 & 6.6 & 6.6 & 7.0 & \\
\hline Real exchange rate (end of period, $1990=100$ ) & 108.3 & 106.0 & 109.1 & 105.6 & 104.4 & 97.4 & Dec-03 \\
\hline Sovereign yield spread (in percent) $3 /$ & $\ldots$ & $\ldots$ & 2.1 & 2.1 & 1.5 & 0.9 & Dec-03 \\
\hline External debt (US\$ billion) 4/ & 9.2 & 11.7 & 11.9 & 15.2 & 15.9 & $\ldots$ & \\
\hline (In percent of GDP) & 11.1 & 14.1 & 13.1 & 18.5 & 17.8 & $\ldots$ & \\
\hline (In percent of exports of goods and services) & 6.9 & 8.2 & 7.1 & 9.9 & 10.1 & $\ldots$ & \\
\hline Of which: Public sector external debt & 0.0 & 0.0 & 0.0 & 0.0 & 0.0 & $\ldots$ & \\
\hline
\end{tabular}

Sources: Data provided by the Singapore authorities and IMF, Information Notice System.

1/ Ratings of the three major local banks.

2/ Based on four-quarter moving average.

3/ Spread of 10-year U.S. dollar-denominated bond issued by DBS over the U.S. government bond.

4/ Based on BIS data; corporate bonds outstanding and the external bank claims by the BIS reporting countries. 
Table 6. Singapore: Illustrative Medium-Term Scenario, 2000-2009

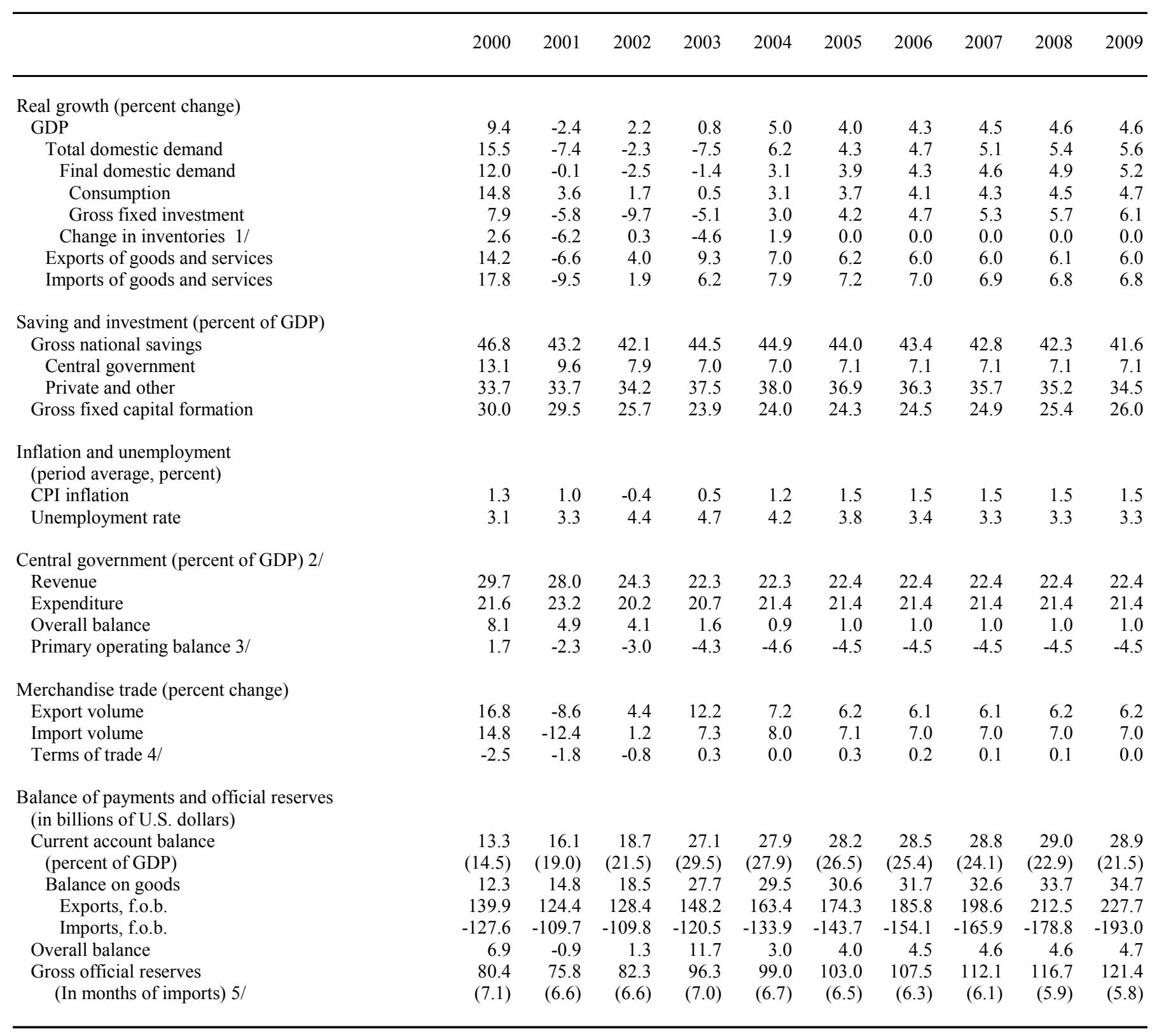

Sources: Data provided by the Singapore authorities; and Fund staff estimates and projections.

1/ Contribution to GDP growth.

2/ On a calendar year basis.

3/ Overall balance excluding capital revenue, investment income, net lending, debt service, and fund transfers.

4/ Based on changes in export and import unit values.

$5 /$ In months of next year's imports of goods and services. 
Key Recommendations of the Economic Review Committee

\begin{tabular}{|c|c|}
\hline Recommendations & Status \\
\hline $\begin{array}{l}\text { Taxation } \\
\text { - Reduce corporate and personal income } \\
\text { tax rates to } 20 \text { percent by year of } \\
\text { assessment (YA) } 2005 \text {. } \\
\text { - Raise GST from } 3 \text { percent to } 5 \text { percent. } \\
\text { - Create GST offset package to help } \\
\text { Singaporeans adjust to GST increase. }\end{array}$ & $\begin{array}{l}\text { - The government cut corporate and top personal tax } \\
\text { rates from } 24.5 \text { percent and } 26 \text { percent respectively to } \\
22 \text { percent in YA2003. The FY2003/04 budget } \\
\text { announced intention to bring both down to } 20 \text { percent } \\
\text { by YA2005. } \\
\text { - The GST rate was raised from } 3 \text { to } 4 \text { percent on January } \\
1,2003 \text {, and to } 5 \text { percent on January } 1,2004 \text {. } \\
\text { - Implemented in } 2003 \text { offset package that includes } \\
\text { income transfers (Economic Restructuring Shares } \\
\text { (ERS)); additional ERS will be distributed in } 2004 \text { and } \\
2005 \text {. }\end{array}$ \\
\hline $\begin{array}{l}\text { Central Provident Fund (CPF) } \\
\text { - Refocus CPF on providing basic } \\
\text { retirement savings, home ownership and } \\
\text { medical needs, and on addressing labor } \\
\text { market flexibility. } \\
\text { - Defer returning CPF contribution rate to } \\
40 \text { percent from } 36 \text { percent ( } 20 \text { percent } \\
\text { employee; } 16 \text { percent employer) for two } \\
\text { years. }\end{array}$ & $\begin{array}{l}\text { - In August 2003, the government made further changes } \\
\text { to earlier ERC recommendations. } \\
\text { - A lower long-term variable contribution rate of } \\
30 \text { percent to } 36 \text { percent (with employer rate between } \\
10 \text { percent and } 16 \text { percent) was set to maintain } \\
\text { competitiveness. For older workers, CPF rate will be } \\
\text { reduced to } 27 \text { percent by } 2006 \text {. } \\
\text { - From October } 1,2003 \text {, cut employer contribution rate } \\
\text { from } 16 \text { percent to } 13 \text { percent. Employees continue to } \\
\text { contribute } 20 \text { percent. } \\
\text { - Increased CPF and Medisave minimum sums; revised } \\
\text { Special and Medisave Accounts contribution rates; } \\
\text { strengthened withdrawal rule at age 55; and further } \\
\text { reduced CPF salary ceiling. }\end{array}$ \\
\hline $\begin{array}{l}\text { Land } \\
\text { - Pursue policies that ensure the adequate } \\
\text { supply of land at competitive, stable } \\
\text { prices. }\end{array}$ & $\begin{array}{l}\text { - Lowered rentals and prices for industrial properties. } \\
\text { - Extended rental rebates for industrial tenants and } \\
\text { lessees until June } 2004 \text {. } \\
\text { - Expanded eligibility for tax deductions for upfront land } \\
\text { premium payments for industrial land to } 60 \text {-year leases } \\
\text { from } 30 \text { years previously. }\end{array}$ \\
\hline
\end{tabular}




\begin{tabular}{|c|c|}
\hline Recommendations & Status \\
\hline $\begin{array}{l}\text { Labor Market } \\
\text { - Enhance labor market flexibility by } \\
\text { raising variable wage component and } \\
\text { drop seniority-based wage system. }\end{array}$ & $\begin{array}{l}\text { - Made several changes to CPF to address labor market } \\
\text { flexibility (see above). } \\
\text { - FY2003/04 budget introduced portable medical } \\
\text { benefits. } \\
\text { - In January 2004, Tripartite Taskforce on Wage } \\
\text { Restructuring encouraged companies to adopt a more } \\
\text { flexible wage model that would increase the variable } \\
\text { component of wages, linked to the performance of the } \\
\text { employee and company. }\end{array}$ \\
\hline $\begin{array}{l}\text { Entrepreneurship and } \\
\text { Internationalization } \\
\text { - GLCs should be commercially run and } \\
\text { operate globally. They should be } \\
\text { reviewed for divestiture. } \\
\text { - To create pro-enterprise environment, } \\
\text { have sunset rule on all licenses, } \\
\text { outsource licensing and other } \\
\text { government functions, allow } \\
\text { enterprises to retain intellectual } \\
\text { property from government projects, } \\
\text { and enact generic competition law. }\end{array}$ & $\begin{array}{l}\text { - Companies to be divested are Ascendas, PSB Corp and } \\
\text { Hdbay. } \\
\text { - Subject non-core government services to market- } \\
\text { testing. } \\
\text { - Exempt from tax foreign income in the form of } \\
\text { dividends, branch profits and services income. } \\
\text { - Allow companies to defer income taxes for two years if } \\
\text { their overseas investment incurs operating losses. }\end{array}$ \\
\hline $\begin{array}{l}\text { Manufacturing and Services Sectors } \\
\text { - Continue to attract multinationals in } \\
\text { electronics, chemicals, biomedical } \\
\text { sciences and engineering sectors. } \\
\text { Encouraging new sectors in industrial } \\
\text { IT, micro-electromechanical systems, } \\
\text { nanotechnology and photonics. } \\
\text { - Continue to develop areas with strong } \\
\text { expertise, like trading and logistics, } \\
\text { ICT, financial services and tourism. In } \\
\text { addition, launch into new sectors such } \\
\text { as healthcare, education and creative } \\
\text { industries. }\end{array}$ & $\begin{array}{l}\text { - Promote private wealth management. Measures include } \\
\text { exempting from income tax foreign trusts administered } \\
\text { by all trust companies from } 2004 \text {. } \\
\text { - Allow approved companies to claim capital allowances } \\
\text { on equipment used by subsidiaries outside Singapore } \\
\text { from FY2003. }\end{array}$ \\
\hline
\end{tabular}




\begin{tabular}{|c|c|}
\hline Recommendations & Status \\
\hline $\begin{array}{l}\text { Human Capital } \\
\text { - Develop the full potential of } \\
\text { individuals through a more flexible } \\
\text { school curriculum. } \\
\text { - Assist unemployed through } \\
\text { comprehensive re-employment } \\
\text { approach with job counseling, } \\
\text { training, job search assistance and } \\
\text { subsidized job attachments. }\end{array}$ & $\begin{array}{l}\text { - A new statutory board (the Singapore Workforce } \\
\text { Development Agency) was established in September } \\
2003 \text { to promote continuing education and training. } \\
\text { - To encourage Singaporeans to upgrade their skills in } \\
\text { preparation for career switches, tax relief for course } \\
\text { fees is increased from } \mathrm{S} \$ 2,500 \text { to } \$ 33,500 \text { and } \\
\text { extended to courses that eventually result in a career } \\
\text { switch. }\end{array}$ \\
\hline
\end{tabular}




\section{SINGAPORE-FUND RELATIONS}

(As of December 31, 2003)

I. Membership Status: Joined August 3, 1966; Article VIII

II. General Resources Account:

Quota

Fund holdings of currency

Reserve position in Fund

III. SDR Department:

Net cumulative allocation

Holdings

IV. Outstanding Purchases and Loans: None

V. Financial Arrangements:

None

VI. Projected Obligations to Fund:

None
SDR million

862.50

483.32

379.27

SDR million

16.48

139.61
Quota

(In percent)

100.00

56.04

43.97

Allocation

(In percent)

100.00

847.42

\section{Exchange Arrangement:}

Singapore follows a policy under which the Singapore dollar is permitted to float. The Monetary Authority of Singapore (MAS) monitors its value against an undisclosed basket of currencies and intervenes in the market to maintain this value within an undisclosed target band. The U.S. dollar is the intervention currency. As of December 31, 2003, US\$1=S\$1.7008.

Singapore has accepted the obligations of Article VIII, Sections 2, 3, and 4 and maintains an exchange rate system that is free of restrictions on the making of payments and transfers for current international transactions.

Singapore maintains restrictions on Singapore-dollar credit facilities, and bond and equity issuance. Singapore-dollar proceeds obtained by non-resident financial entities (such as banks, merchant banks, finance companies, and hedge funds) from loans, equity listings or bond issuance to finance activities outside Singapore have to be swapped or converted into foreign currency upon draw-down. Financial institutions are prohibited from extending Singapore-dollar credit facilities in excess of S\$5 million to nonresident financial entities if there is reason to believe that the Singapore-dollar proceeds may be used for Singapore-dollar currency speculation.

\section{Last Article IV Consultation:}

The 2002 Article IV consultation discussions were held in Singapore during September 5-17, 2002, and the consultation was concluded by the Executive Board on December 9, 2002. 


\section{FSAP Participation:}

The FSAP has been undertaken in conjunction with the 2003 Article IV consultation. FSAP missions took place in November 2002, July-August 2003, and September 2003.

X. Technical Assistance: None

XI. Resident Representative: None 


\section{SINGAPORE-STATISTICAL ISSUES}

1. Singapore provides data to the Fund on a generally timely basis and meets the SDDS specifications for the coverage, periodicity, and timeliness of the data, and for the dissemination of advance release calendars. However, there are a number of deficiencies in statistical practice, particularly in the external and fiscal areas.

- In early 2003, the Singapore Department of Statistics (DOS) completed a rebasing of the Singapore System of National Accounts to reference year 1995 from 1990. The DOS also made improvements in data sources and methodology. One issue addressed in this exercise was the treatment of a value-added tax, namely the Goods and Services Tax (GST), introduced in April 1994. Also, a reconciliation of various national accounts estimates was conducted, resulting in lower statistical discrepancies, and work on further improvements is ongoing.

- Merchandise trade statistics do not fully include trade with Indonesia, although trade transactions with Indonesia are captured elsewhere in the current account of the balance of payments. In January 2004, the authorities released some trade data with Indonesia covering 2003. The authorities plan to publish additional information on trade with Indonesia as part of their plans to accede to the Harmonized System Convention of the World Customs Organization (WCO).

- In December 2003, the DOS introduced a new reporting format for the BOP's services account that includes the standard services components (except communication services), in line with the fifth edition of the Balance of Payments Manual (BPM5). Other goods and services receipts and payments, which are substantial, used to be not disaggregated. The DOS used data from the Survey on International Trade in Services (launched in 1996) as an additional source for the compilation of more detailed services statistics.

- Information on government assets held abroad is not published nor provided to the Fund. Interest on these assets and debt service payments on domestic debt made from the extrabudgetary Government Securities Fund are published on an annual basis, but are not fully reflected in the fiscal position. More generally, data on the financial position of the consolidated public sector are not published. Singapore has nevertheless complied with the expanded SDDS requirements to include data on the international investment position.

2. During the course of the year, staff receive a steady flow of economic data from published sources, via the Reuters monitor, various official websites, and the TREND database. Most data are received on a timely basis.

3. Annual balance of payments data are reported to STA each year. Quarterly financial account data as provided to STA by the authorities are not sufficiently detailed for publication in the International Financial Statistics. The authorities are working to improve their data sources for the compilation of quarterly estimates of financial flows. 


\section{Singapore-Core Statistical Indicators}

(As of January 30, 2004)

\begin{tabular}{|c|c|c|c|c|c|c|c|c|c|c|c|c|}
\hline & $\begin{array}{c}\text { Exchange } \\
\text { Rates }\end{array}$ & $\begin{array}{l}\text { International } \\
\text { Reserves }\end{array}$ & $\begin{array}{c}\text { Reserve/ } \\
\text { Base } \\
\text { Money }\end{array}$ & $\begin{array}{c}\text { Central } \\
\text { Bank } \\
\text { Balance } \\
\text { Sheet } \\
\end{array}$ & $\begin{array}{l}\text { Broad } \\
\text { Money }\end{array}$ & $\begin{array}{c}\text { Interest } \\
\text { Rates }\end{array}$ & $\begin{array}{l}\text { Consumer } \\
\text { Price Index }\end{array}$ & $\begin{array}{l}\text { Exports/ } \\
\text { Imports }\end{array}$ & $\begin{array}{l}\text { Current } \\
\text { Account }\end{array}$ & $\begin{array}{c}\text { Overall } \\
\text { Government } \\
\text { Balance }\end{array}$ & GDP & $\begin{array}{c}\text { External } \\
\text { Debt/Debt } \\
\text { Service 1/ }\end{array}$ \\
\hline $\begin{array}{l}\text { Date of latest } \\
\text { observation }\end{array}$ & $1 / 30 / 04$ & $12 / 03$ & $12 / 03$ & $12 / 03$ & $12 / 03$ & $1 / 30 / 04$ & $12 / 03$ & $12 / 03$ & $\mathrm{Q} 3 / 03$ & Q3/03 & Q3/03 & $\ldots$ \\
\hline Date received & $1 / 30 / 04$ & $1 / 04$ & $1 / 04$ & $1 / 04$ & $1 / 04$ & $1 / 30 / 04$ & $1 / 04$ & $1 / 04$ & $11 / 03$ & $11 / 03$ & $11 / 03$ & $\ldots$ \\
\hline $\begin{array}{l}\text { Frequency of } \\
\text { data } 2 /\end{array}$ & D & M & M & M & M & D & M & M & Q & Q & Q & $\ldots$ \\
\hline $\begin{array}{l}\text { Frequency of } \\
\text { Reporting } 2 /\end{array}$ & $\mathrm{D}$ & M & M & M & M & D & M & M & $\mathrm{Q}$ & Q & Q & $\ldots$ \\
\hline Source of data $3 /$ & $\mathrm{N}$ & $\mathrm{N}$ & $\mathrm{N}$ & $\mathrm{N}$ & $\mathrm{N}$ & $\mathrm{N}$ & $\mathrm{N}$ & $\mathrm{N}$ & $\mathrm{N}$ & $\mathrm{N}$ & $\mathrm{N}$ & $\ldots$ \\
\hline $\begin{array}{l}\text { Mode of } \\
\text { reporting 4/ }\end{array}$ & E & E & E & $\mathrm{E}$ & $\mathrm{E}$ & E & $\mathrm{E}$ & $\mathrm{E}$ & $\mathrm{E}$ & E & E & $\ldots$ \\
\hline Confidentiality & Public & Public & Public & Public & Public & Public & Public & Public & Public & Public & Public & $\ldots$ \\
\hline $\begin{array}{l}\text { Frequency of } \\
\text { publication 2/ }\end{array}$ & D & M & M & M & M & D & M & M & Q & Q & Q & $\ldots$ \\
\hline
\end{tabular}

1/ Official external debt is zero; data from official sources on private external debt are not available, although a survey to improve reporting in this area has recently been launched.

2/ D-daily; M-monthly; Q-quarterly.

3/ A-direct reporting by authorities; N-official publications and websites.

4/ E-electronic data transfer. 
INTERNATIONAL MONETARY FUND

SINGAPORE

\title{
Staff Report for the 2003 Article IV Consultation
}

\author{
Supplementary Information \\ Prepared by Staff Representatives for the 2003 Consultation with Singapore \\ Approved by Masahiko Takeda and Juha Kähkönen
}

March 10, 2004

\begin{abstract}
1. This supplement provides information on recent economic and policy developments that has become available since the release of the staff report. The information does not alter the thrust of the staff appraisal.
\end{abstract}

2. The GDP outturn for $\mathbf{2 0 0 3}$ has been revised upward by the authorities (Table). Newly released data indicate that the economy grew by 1.1 percent in 2003, compared to the estimate of 0.8 percent presented in the staff report. The data suggest that the SARS-induced contraction of the second quarter amounted to 7 percent (seasonally adjusted annualized q/q basis), somewhat less severe than 10 percent previously estimated, and that the rebound in the fourth quarter was a strong 11 percent, compared to 8 percent previously estimated. While the staff's 2004 GDP growth projection remains at 5 percent, given the positive signs of recovery and strong global environment, the government has raised its official growth forecast by $1 / 2$ percentage point, to 3.5 percent to 5.5 percent.

3. The breakdown of GDP growth for $\mathbf{2 0 0 3}$ remains largely as described in the staff report. The recovery during the second half of the year was led by external demand, with domestic demand, particularly investment, remaining weak. The current account surplus has been revised slightly upward, to US $\$ 28$ billion, equivalent to 31 percent of GDP, and official reserves have increased to US\$101 billion at end-February 2004. CPI inflation edged up to 1.3 percent $(\mathrm{y} / \mathrm{y})$ in January, from 0.7 percent in the previous month, partly due to the 1 percentage point increase in the Goods and Services Tax that took effect on January 1.

4. The FY2004/05 budget was presented to Parliament at end-February (fiscal year beginning April 1). Detailed data to assess the budget stance in a format consistent with the presentation in the staff report (based on GFS methodology) will become available to staff only after the budget is approved around end-March. However, based on preliminary information contained in the Minister of Finance's budget speech, the proposed budget appears to be broadly in line with that envisaged during the consultation discussions. Based on the staff's estimates, the budget targets a slightly higher overall surplus (by about 0.2 percent of GDP) compared to the latest projected outturn for FY2003/04. Such a target would amount to an unchanged fiscal stance (i.e., no provision or withdrawal of fiscal stimulus). 
5. As anticipated in the staff report, the budget contains a number of tax side initiatives to support the recovery and enhance competitiveness. These include: (i) a 2 percentage point cut in the corporate income tax rate to 20 percent beginning in 2005; (ii) an extension of the tax exemption to individuals on foreign-sourced and domestic financial investment income beginning in 2005; and (iii) tax exemptions for start-up companies. An anticipated 2 percentage point cut in the top personal income tax rate (an ERC recommendation) is being deferred, given the authorities' desire to preserve revenues. The sectoral distribution of spending is to be largely unchanged from the previous year. 
Table. Singapore: Revisions to Selected Economic Indicators for 2003

\begin{tabular}{lrr}
\hline & 2003 & \\
\cline { 2 - 3 } & Staff Report & Revised \\
\hline Growth (percent change) & & \\
Real GDP & 0.8 & 1.1 \\
$\quad$ Total domestic demand & -7.5 & -9.6 \\
$\quad$ Final domestic demand & -1.4 & -1.6 \\
$\quad$ Consumption & 0.5 & -0.4 \\
$\quad$ Gross fixed investment & -5.1 & -3.8 \\
$\quad$ Change in inventories (contribution to GDP growth) & -4.6 & -6.2 \\
Net exports (contribution to GDP growth) & 7.2 & 8.7 \\
Saving and investment (percent of GDP) & & \\
Gross national savings & 44.5 & 44.2 \\
Gross capital formation & 15.0 & 13.4 \\
Central government budget (percent of GDP) 1/ 2/ & & \\
Revenue & 22.0 & 21.1 \\
Expenditure & 21.3 & 20.1 \\
Overall balance & 0.7 & 1.0 \\
Primary operating balance 3/ & -4.8 & -3.9 \\
Balance of payments (US\$ billion) & & \\
Current account balance & & \\
(In percent of GDP) & & \\
Balance on goods & 27.1 & 28.2 \\
$\quad$ Exports, f.o.b. & $(29.5)$ & $(30.9)$ \\
Imports, f.o.b. & 27.7 & 29.3 \\
Overall balance & 148.2 & 157.8 \\
\hline
\end{tabular}

Sources: Data provided by the Singapore authorities; and Fund staff estimates and projections.

1/ Fiscal year beginning on April 1.

2/ Data for staff report (2/23/04) include supplementary budget measures announced in mid-April and in late August.

3/ Overall balance excluding capital revenue, investment income, net lending, debt service, and fund transfers. 


\section{INTERNATIONAL MONETARY FUND}

EXTERNAL

\section{IMF Concludes 2003 Article IV Consultation with Singapore}

On March 15, 2004, the Executive Board of the International Monetary Fund (IMF) concluded the Article IV consultation with Singapore. ${ }^{1}$

\section{Background}

After averaging over 9 percent in the decade prior to the Asian financial crisis, economic growth in Singapore has slowed in recent years. This outcome is attributable to three major recent shocks: (i) the Asian crisis in 1997-98; (ii) the bursting of the tech bubble in 2000-01; and more recently, (iii) the outbreak of Severe Acute Respiratory Syndrome (SARS) in early 2003, exacerbated by uncertainties related to international terrorism and the war in Iraq.

The economic shocks have come as Singapore is also facing structural challenges owing to competition from low-cost regional economies, including China and India.

Economic growth registered 1.1 percent in 2003, down from 2.2 percent in 2002 . The slowdown was due mainly to the outbreak of SARS in March 2003, resulting in rising unemployment and a sharp economic contraction in the second quarter. Falling domestic demand (particularly investment) contributed to the sharp contraction. However, the economy began to recover strongly in the second half, led by a rebound in the services sector and strong external demand. Inflation remained subdued in 2003 after a period of mild deflation in 2002. Reflecting weak domestic demand conditions and strong external demand, the current account surplus increased sharply to 31 percent of GDP in 2003; official international reserves increased by

\footnotetext{
${ }^{1}$ Under Article IV of the IMF's Articles of Agreement, the IMF holds bilateral discussions with members, usually every year. A staff team visits the country, collects economic and financial information, and discusses with officials the country's economic developments and policies. On return to headquarters, the staff prepares a report, which forms the basis for discussion by the Executive Board. At the conclusion of the discussion, the Managing Director, as Chairman of the Board, summarizes the views of Executive Directors, and this summary is transmitted to the country's authorities.
} 
US $\$ 14$ billion, to stand at US $\$ 96$ billion at end-2003. The Singapore dollar depreciated by $3 \frac{1}{2}$ percent (period average) in nominal effective terms in 2003.

The government implemented a supportive macroeconomic policy stance to support the economy in response to the SARS-induced economic downturn. Fiscal stimulus was provided through higher development expenditure and two supplementary budgets (consisting largely of targeted assistance to SARS-inflicted sectors, low-income earners and the unemployed, and of acceleration of infrastructure projects). In addition, supply-side measures, including a reduction in the Central Provident Fund (CPF) employer contribution rate by 3 percentage points from October 2003, were taken to reduce business costs. Monetary policy was also eased in mid2003 with the recentering of the exchange rate band at the prevailing lower level of the tradeweighted exchange rate.

Recent indicators confirm that a strong recovery is underway, and the staff's outlook is for growth to rebound by around 5 percent in 2004. CPI inflation is projected to remain modest at around 1 percent in 2004, due in part to the soft labor market conditions. While the recovery should continue to benefit from strong external demand, domestic demand should also begin to contribute, with a modest recovery in consumption as confidence improves and the unemployment rate begins to decline, as well as a pickup in investment as the slack in the economy dissipates and inventories are rebuilt. The risks to the outlook are broadly balanced. The main downside risks relate to the sustainability of the global and regional recovery, and the possibility that the high unemployment rate and still depressed property market could become drags on growth. At the same time, there is some upside potential to the 2004 forecast, especially if the pickup of external demand gathers further momentum, and growth in the export sector spills over to domestic demand. Over the medium term, the staff expects growth to be around 4-5 percent.

Increasing competition from low-cost regional economies has raised concerns within Singapore about the economy's medium-term competitiveness and growth prospects, along with an increasing awareness of the economy's vulnerability to external shocks (especially in the electronics sector, which dominates the country's manufacturing exports). The government's adoption of the recommendations of the Economic Review Committee (ERC) is a response to these challenges. The ERC was established in late 2001 to evaluate Singapore's long-term strategy and the need for structural change. Finalized in early 2003 , the ERC recommendations seek to enhance competitiveness and entrepreneurship and to diversify the economy. Key elements of the strategy include a shift from direct to indirect taxation (including a reduction in personal and corporate income tax rates), reforms to the CPF scheme aimed at enhancing its core retirement savings objective, the divestment of non-strategic government-linked companies (GLCs), and policies to foster greater labor market flexibility and strengthen job training programs.

\section{Executive Board Assessment}

Executive Directors noted that the economy had suffered another bout of turbulence in 2003 due to the SARS outbreak, the latest in a series of economic shocks in recent years. Directors commended the authorities for their continued pragmatic use of countercyclical fiscal and 
monetary policies, noting that supportive policies had cushioned the impact of the SARSinduced economic downturn and were contributing to a strong economic recovery.

They emphasized that the most significant policy challenges are to advance structural reforms to enhance the economy's medium-term competitiveness and growth prospects, and improve its resiliency to external shocks.

While the near-term economic outlook has brightened, Directors observed that there remains a sizeable output gap, unemployment is still high by historical standards, and the recovery has been based on external demand. They therefore encouraged the authorities to maintain a supportive macroeconomic policy stance in the period ahead, until the recovery broadens.

On fiscal policy, Directors endorsed the package of measures taken last year to cushion the impact of the SARS outbreak, which included providing assistance to SARS-afflicted sectors of the economy and a package of rebates, incentives, and infrastructure projects. They also welcomed civil service wage restraint, as an important wage-setting signal to the private sector, given the soft labor market conditions, and a reduction in the employers' contribution to the Central Provident Fund, as a means to reduce business costs.

Directors endorsed the authorities' intention to maintain a supportive fiscal stance in the coming year, as outlined in the recent budget proposal for fiscal year 2004/05, and plans to continue cutting income tax rates and reorienting the tax system toward taxes on goods and services. They also supported reducing unemployment through job training and search programs, and saw some additional scope for a strengthened and well-structured social safety net for the unemployed. While supporting continued flexibility in the fiscal position, Directors endorsed the authorities' intention to achieve budget balance over the medium term to address concerns about rising health care and pension costs.

Directors endorsed the easing of monetary policy in mid-2003 in response to the economic downturn. In the absence of inflationary pressures, and with domestic demand still weak, they considered it appropriate to maintain a supportive monetary policy stance. Directors observed that Singapore's exchange-rate-centered monetary policy framework has continued to serve the economy well. They generally were of the view that once the recovery takes hold, there would be scope for some tightening of the current easy monetary policy stance, consistent with the price stability objective which, together with the economic recovery, would enable Singapore to contribute to an orderly adjustment of global current account imbalances. Directors welcomed ongoing initiatives to enhance the transparency of the monetary policy setting process and disseminate operational background materials, and encouraged the authorities to continue these efforts, which have improved the effectiveness of the monetary policy framework.

With regard to structural reforms, Directors supported the authorities' efforts to enhance the economy's competitiveness and flexibility. In view of increasing competition from abroad, they urged the authorities to continue to facilitate Singapore's shift from lower-end manufacturing and services to higher value-added activities, by providing a policy environment conducive to stimulating private and foreign direct investment. In this regard, Directors welcomed the authorities' endorsement of the Economic Review Committee recommendations, emphasizing, in particular, the importance of initiatives to lower income tax rates, enhance labor market 
flexibility, and reduce the government's role in the economy through the divestment of government-linked companies. They encouraged the authorities to consider accelerating the divestment of GLCs, where appropriate.

Directors highlighted the importance of recent steps to encourage a higher level of savings for retirees under the CPF scheme. They supported initiatives to enhance the returns to the CPF assets by permitting savers to invest in privately managed investment funds and giving the fund more marketable instruments, and to refocus the fund on its core function as a retirement scheme, including by reducing its role in housing finance. Although Directors supported a reduction in the CPF's contribution rate to reduce employers' costs, they considered that an early return to a stable contribution rate would be useful.

Based on the findings of the Financial System Stability Assessment (FSSA), Directors highlighted the resiliency of Singapore's financial system, despite a number of economic shocks in recent years. They commended the high degree of observance of international standards and codes, and ongoing initiatives to further strengthen corporate governance and the legal and regulatory framework for risk-based supervision. Directors supported the ongoing review of the Monetary Authority of Singapore (MAS) Act to strengthen the MAS' accountability and independence. To further enhance financial sector stability, they encouraged the early implementation of the FSSA recommendations, including those to strengthen the MAS' macroprudential monitoring and further improve the transparency of supervisory actions.

Directors also saw scope to enhance the transparency of fiscal policy information.

They welcomed the authorities' intention to improve the published database in terms of timeliness, frequency, comprehensiveness, and format, and they emphasized the importance of developing a consolidated set of fiscal accounts. They also encouraged the authorities to undertake a fiscal Report on the Observance of Standards and Codes. Directors welcomed the authorities' decision to publish the Staff Report, the FSSA and its Supplement, and other papers related to the Article IV consultation.

Directors commended the authorities on their continued commitment to multilateral trade liberalization and strong support for free trade, which has resulted in a number of free trade agreements. They concurred with the authorities that such agreements could serve as a catalyst to broader trade liberalization initiatives.

Public Information Notices (PINs) are issued, (i) at the request of a member country, following the conclusion of the Article IV consultation for countries seeking to make known the views of the IMF to the public. This action is intended to strengthen IMF surveillance over the economic policies of member countries by increasing the transparency of the IMF's assessment of these policies; and (ii) following policy discussions in the Executive Board at the decision of the Board. 
Singapore: Selected Economic Indicators

\begin{tabular}{|c|c|c|c|c|c|}
\hline & 2000 & 2001 & 2002 & $\begin{array}{r}2003 \\
\text { Est. }\end{array}$ & $\begin{array}{l}2004 \\
\text { Proj. }\end{array}$ \\
\hline \multicolumn{6}{|l|}{ Growth (percent change) } \\
\hline Real GDP & 9.4 & -2.4 & 2.2 & 1.1 & 5.0 \\
\hline Consumption & 14.8 & 3.6 & 1.7 & -0.4 & 3.1 \\
\hline Gross fixed investment & 7.9 & -5.8 & -9.7 & -3.8 & 3.0 \\
\hline Change in inventories $1 /$ & 2.6 & -6.2 & 0.3 & -6.2 & 1.9 \\
\hline Net exports $1 /$ & -2.6 & 3.9 & 4.1 & 8.7 & 0.8 \\
\hline \multicolumn{6}{|l|}{ Saving and investment (percent of GDP) } \\
\hline Gross national savings & 46.8 & 43.2 & 42.1 & 44.2 & 44.9 \\
\hline Gross capital formation & 32.3 & 24.2 & 20.6 & 13.4 & 17.0 \\
\hline \multicolumn{6}{|l|}{ Inflation and unemployment (period average, percent) } \\
\hline CPI inflation & 1.3 & 1.0 & -0.4 & 0.5 & 1.2 \\
\hline Unemployment rate & 3.1 & 3.3 & 4.4 & 4.7 & 4.2 \\
\hline \multicolumn{6}{|l|}{ Central government (percent of GDP) 2/ } \\
\hline Revenue & 29.6 & 27.5 & 23.2 & 21.1 & 21.2 \\
\hline Expenditure & 20.7 & 24.0 & 18.9 & 20.1 & 20.0 \\
\hline Overall balance & 8.9 & 3.5 & 4.3 & 1.0 & 1.2 \\
\hline Primary operating balance $3 /$ & 1.1 & -3.5 & -2.8 & -3.9 & -3.6 \\
\hline \multicolumn{6}{|l|}{ Money and credit (end of period, percent change) } \\
\hline M3 & -1.8 & 4.0 & -0.8 & 5.9 & $\ldots$ \\
\hline Credit to private sector & 5.9 & 16.3 & -8.6 & 5.4 & $\ldots$ \\
\hline Interest rate (three-month interbank, in percent) & 2.8 & 1.3 & 0.8 & 0.8 & $\ldots$ \\
\hline \multicolumn{6}{|l|}{ Balance of payments (US\$ billion) } \\
\hline Current account balance & 13.3 & 16.1 & 18.7 & 28.2 & 27.9 \\
\hline (In percent of GDP) & $(14.5)$ & $(19.0)$ & $(21.5)$ & $(30.9)$ & $(27.9)$ \\
\hline Overall balance & 6.9 & -0.9 & 1.3 & 6.8 & 3.0 \\
\hline Gross official reserves & 80.4 & 75.8 & 82.3 & 96.3 & $\ldots$ \\
\hline \multicolumn{6}{|l|}{ Exchange rate } \\
\hline S\$/US\$ (end of period) & 1.732 & 1.851 & 1.737 & 1.701 & $\ldots$ \\
\hline Nominal effective exchange rate $4 /$ & 119.5 & 121.2 & 120.2 & 115.8 & $\ldots$ \\
\hline Real effective exchange rate 4/ & 106.9 & 107.7 & 105.2 & 100.3 & $\ldots$ \\
\hline
\end{tabular}

Sources: Data provided by the Singapore authorities; and IMF staff estimates and projections.

$1 /$ Contribution to GDP growth.

2/ Fiscal year beginning on April 1.

3/ Overall balance excluding capital revenue, investment income, net lending and fund transfers.

4/ IMF, Information Notice System monthly index (1990=100); period average. 